\title{
Modelling of Liquid-liquid Equilibria in Quasi-seven-component Systems with Deep Eutectic Solvents as Extraction Media
}

\author{
M. Rogošić* and K. Zagajski Kučan
}

University of Zagreb, Faculty of Chemical Engineering and Technology, Marulićev trg 19, HR-10 000 Zagreb, Croatia

\begin{abstract}
Liquid-liquid equilibria were experimentally investigated in systems in which the first component was aliphatic ( $n$-hexane, $n$-heptane or $i$-octane) or aromatic hydrocarbon (toluene), the second component was pyridine or thiophene, and the third quasi-component was DES consisting of choline chloride and glycerol or choline chloride and ethylene glycol, at $25{ }^{\circ} \mathrm{C}$ and atmospheric pressure. The equilibria were successfully described by the NRTL and UNIQUAC models. The same models were successfully applied to describe the liquid-liquid equilibria in quasi-seven-component systems that comprised all the mentioned low molecular weight components and one DES. The restrictions of the models were discussed; it seems that the preference can be given to the UNIQUAC model.
\end{abstract}

\section{Keywords}

Deep eutectic solvents, NRTL, UNIQUAC, model fuel, liquid-liquid equilibria

\section{Introduction}

By definition, green solvents are solvents that have minimal negative environmental impact arising from the use of these solvents in industry. Most industrial processes use harmful organic solvents. For such a process to be ecologically acceptable, it is necessary to replace the harmful solvents with solvents that have more favourable EHS (environmental, health and safety) properties, biosolvents, supercritical fluids, ionic liquids or deep eutectic solvents. ${ }^{1}$

Deep eutectic solvents (DES) are mixtures of hydrogen bond donors and acceptors with a melting point lower than the melting point of their individual components. ${ }^{2}$ The most important properties for their application in separation processes are: non-flammability, negligible vapour pressure, chemical and thermal stability, and high capacity for dissolution of various types of substances. ${ }^{3}$ Moreover, it is relatively easy to regenerate them and even to use them several times without purification. ${ }^{4,5}$ The easy adjustment of their properties by simple replacement of the hydrogen bond donor or acceptor allows them to be widely applied, so they have found their place in the treatment of motor fuels. ${ }^{6}$

Among the motor fuel treatment processes, those used for removing harmful sulphur and nitrogen compounds are particularly important, which is also stipulated by the legislation. The most commonly used commercial process of desulphurization of hydrocarbon fuels is hydrodesulphurization (HDS). ${ }^{7}$ Due to high consumption of energy, hydrogen and catalysts, the commercial HDS process has to be replaced by cheaper and more efficient ones. ${ }^{8}$ Among the alternative processes, extractive desulphurization (EDS) is particularly interesting, being characterized by mild extrac-

*Corresponding author: Marko Rogošić, Ph.D.

email: mrogosic@fkit.hr tion conditions (low temperature and atmospheric pressure). In particular, extraction desulphurization using ionic liquids was investigated. However, authors who have used model solutions containing sulphur, nitrogen and aromatic compounds as well as real refinery samples have proven that denitrification and dearomatization are being carried out simultaneously with desulphurization. ${ }^{9-11}$ Because of the toxicity of ionic liquids and their high cost, DESs are being investigated more recently in the processes of extractive desulphurization, ${ }^{12-14}$ denitrification ${ }^{15,16}$ and dearomatization. ${ }^{17}$ In all the mentioned cases, model fuels, i.e. mixtures of one hydrocarbon and one characteristic sulphur or nitrogen compound, were investigated, and the observed extraction equilibrium was described by NRTL model ${ }^{16,17}$ with a slightly larger success or with COSMO-RS model, ${ }^{16}$ somewhat less successfully.

According to our best knowledge, there is no research to deal with the simultaneous extraction of aromatic, sulphur and nitrogen compounds by a DES, and only such studies may point to effects such as the possible suppression of the solubility of paraffins in ionic liquids by aromatic, sulphur and nitrogen compounds..$^{18}$ In our previous works ${ }^{19,20}$ similar studies have been described on model seven-component systems containing three aliphatic hydrocarbons, one aromatic hydrocarbon, one nitrogen- and one sulphur-containing compound and an ionic liquid (IL). Those studies also contain a thermodynamic description of the extraction equilibrium by the NRTL and UNIQUAC models, including a detailed description of the method of transferring the parameters from the three-component to the seven-component systems. The described procedure will be adapted in this paper for the systems containing DESs instead of ionic liquids as extraction media. Particular emphasis will be placed on the limitations of thermodynamic modelling in DES-containing systems that did not exist in the systems with ionic liquids. 


\section{Experimental}

\subsection{Chemicals}

The list of chemicals is given in Table 1. The chemicals were used without further purification. DES components, choline chloride and glycerol, or choline chloride and ethylene glycol were mixed at the given molar ratios. The resulting mixtures were stirred in a rotary vacuum evaporator at $60{ }^{\circ} \mathrm{C}$ and 250 mbar until a homogeneous colourless liquid was obtained, presumably anhydrous. The density of the prepared DESs was measured by a Mettler Toledo densitometer Densito $30 \mathrm{PX}$ at $25^{\circ} \mathrm{C}$.

\subsection{DES as a quasi-component}

Unlike ionic liquids, DESs themselves are not well-defined chemical compounds, but rather two-component systems consisting of a hydrogen bond donor and hydrogen bond acceptor in the ratio determined by the very preparation process. The components of DES are kept together by stronger or weaker hydrogen bonds, whereby the hydrogen bonds themselves do not determine the eutectic character of the mixture. Namely, the phenomenon of binary eutectics is characteristic for all two-component systems that are completely immiscible in solid phase or exhibit limited immiscibility, which means that they cannot crystallize in a common crystal lattice. Since the latter systems are relatively rare, binary eutectics are rather a rule than an exception. Hydrogen bonds here only induce the non-ideality of the liquid phase, which can produce shifting of the characteristic parameters of the binary eutectic mixture, i.e. its melting point and composition, with respect to the parameters expected for the ideal solutions. The addition of any component to a system commonly referred to as DES, can affect the strength of hydrogen bonding between its components, or their mutual miscibility. This fact influenced the experimental procedure applied in this paper. DESs prepared and investigated in this paper are listed in Table 2.

\subsection{Tie lines in quasi-three-component systems}

The quasi-three-component systems in which the first component is aliphatic ( $n$-hexane, $n$-heptane or $i$-octane) or aromatic hydrocarbon (toluene), the second component is pyridine or thiophene, and the third quasi-component is DES consisting of choline chloride and glycerol, or choline chloride and ethylene glycol may be considered as class II systems with respect to the liquid-liquid equilibrium. Namely, pyridine and thiophene are completely miscible with all investigated hydrocarbons. Hydrocarbons and DESs are completely immiscible, as confirmed by NMR. Namely, the ${ }^{1} \mathrm{H}$ NMR spectra collected on a Bruker AV300 apparatus did not indicate measurable traces of DESs in hydrocarbons or hydrocarbons in DESs. Regarding the miscibility of pyridine with DESs or thiophene with DESs, DESs

Table 1 - Chemicals

Tablica 1 - Kemikalije

\begin{tabular}{|c|c|c|c|c|}
\hline $\begin{array}{l}\text { Chemical } \\
\text { Kemikalija }\end{array}$ & $\begin{array}{l}\text { Manufacturer } \\
\text { Proizvođač }\end{array}$ & $\begin{array}{l}\text { Purity/mass \% } \\
\text { Čistoća/mas. \% }\end{array}$ & $\begin{array}{c}\text { CAS number } \\
\text { CAS (registarski) broj }\end{array}$ & $\begin{array}{c}\text { Molar mass } / \mathrm{g} \mathrm{mol}^{-1} \\
\text { Molarna masa } / \mathrm{g} \mathrm{mol}^{-1}\end{array}$ \\
\hline n-hexane & Carlo Erba Reagenti & $>98.5$ & $110-54-3$ & 86.18 \\
\hline n-heptane & Carlo Erba Reagenti & 99 & $142-82-5$ & 100.21 \\
\hline i-octane & Kemika & $>99.5$ & $540-84-1$ & 114.23 \\
\hline toluene & Lachner & 99.28 & $108-88-3$ & 92.14 \\
\hline thiophene & Acros Organics & 99 & $110-02-1$ & 84.14 \\
\hline pyridine & Carlo Erba Reagenti & $>99$ & $110-86-1$ & 79.10 \\
\hline choline chloride & Acros Organics & 99 & $67-48-1$ & 139.62 \\
\hline glycerol & Kemika & $>99.5$ & $56-81-5$ & 92.10 \\
\hline ethylene glycol & VWR Chemicals & 99.7 & $107-21-1$ & 62.07 \\
\hline
\end{tabular}

Table 2 - Deep eutectic solvent systems studied

Tablica 2 - Istraživana niskotemperaturna eutektička otapala

\begin{tabular}{|c|c|c|c|c|}
\hline $\begin{array}{l}\text { Hydrogen bond acceptor } \\
\text { Akceptor vodikove veze }\end{array}$ & $\begin{array}{l}\text { Hydrogen bond donor } \\
\text { Donor vodikove veze }\end{array}$ & $\begin{array}{l}\text { Molar ratio } \\
\text { Molarni omjer }\end{array}$ & $\begin{array}{c}\text { Molar mass } / \mathrm{g} \mathrm{mol}^{-1} \\
\text { Molarna masa } / \mathrm{g} \mathrm{mol}^{-1}\end{array}$ & $\begin{array}{l}\text { Density } / \mathrm{g} \mathrm{cm}^{-3} \\
\text { Gustoća } / \mathrm{g} \mathrm{cm}^{-3}\end{array}$ \\
\hline choline chloride $(\mathrm{ChCl})$ & ethylene glycol (EG) & $1: 2$ & 263.760 & 1.1260 \\
\hline choline chloride $(\mathrm{ChCl})$ & ethylene glycol (EG) & $1: 3$ & 325.830 & 1.1241 \\
\hline choline chloride $(\mathrm{ChCl})$ & ethylene glycol (EG) & $1: 3.5$ & 356.865 & 1.1231 \\
\hline choline chloride (ChCl) & glycerol (Gly) & $1: 1.5$ & 277.755 & 1.1888 \\
\hline choline chloride $(\mathrm{ChCl})$ & glycerol (Gly) & $1: 2$ & 323.800 & 1.2006 \\
\hline choline chloride (ChCl) & glycerol (Gly) & $1: 3$ & 415.890 & 1.2082 \\
\hline
\end{tabular}


are dissolved neither in pyridine nor in thiophene; the solubility of pyridine and thiophene in DESs is determined by a simple combination of titration and gravimetry. Pyridine or thiophene is added dropwise into the DESs until turbidity is observed indicating the appearance of the second phase in the system. Maximum solubility was determined from the mass of the added pyridine or thiophene. Regarding the immiscibility of hydrocarbons and DESs, the results are consistent with literature findings in similar systems. ${ }^{16}$ In pyridine systems, at higher pyridine content $\left(w_{2}\right.$ higher than approximately $0.4-0.6$, depending on the DES), at least one additional phase appears, i.e. the DES becomes unstable. This phenomenon was not observed in thiophene systems.

From this, an appropriate experimental procedure for the determination of tie lines was constructed. Mixtures of hydrocarbons and pyridine of different compositions were prepared, whose refractive index at $25^{\circ} \mathrm{C}$ was determined on Abbe's refractometer (Model RMI, Exacta Optech, precision \pm 0.0001$)$. The obtained dependence of the refractive index on composition can be described by the empirical expression:

$$
w_{2}=A \cdot n_{\mathrm{D}, 25}^{3}+B \cdot n_{\mathrm{D}, 25}^{2}+C \cdot n_{\mathrm{D}, 25}+D
$$

which serves as a calibration function of the raffinate phase.

Subsequently, by weighing on an analytical balance, quasi-three-component mixtures were prepared with approximately equal masses of hydrocarbons and DES and a varying pyridine content. The exact composition was calculated from the component masses. The resulting twophase mixtures were stirred for $24 \mathrm{~h}$ in a thermostated air bath at $25{ }^{\circ} \mathrm{C}(220 \mathrm{rpm})$. After separation of equilibrium phases, the refractive indices were measured, which were converted into raffinate phase compositions by means of the calibration functions. Compositions of extract phases were determined from the mass balance, from the known overall compositions and compositions of the raffinate phase, whereby preliminary experiments verified the assumption that there are no measurable hydrocarbon quantities in the extract phase.

\subsection{Extraction experiments in quasi-seven-component systems}

The quasi-seven-component model systems consist of a six-component model fuel comprising three aliphatic hydrocarbons: $n$-hexane, $n$-heptane and $i$-octane, toluene as an aromatic hydrocarbon, as well as thiophene and pyridine as a sulphur and nitrogen compound representative, respectively; the seventh quasi-component is DES as an extraction medium. The model fuel solution was prepared to mimic the composition of Fluid Catalytic Cracking (FCC) gasoline. ${ }^{10}$ It consisted of approximately $26 \%$ of $n$-hexane, $26 \%$ of $n$-heptane, $26 \%$ of $i$-octane, $10 \%$ of toluene, $6 \%$ of thiophene and $6 \%$ of pyridine.

Experiments were performed at different mass ratios of DES/model fuel $\left(0.25,0.50,0.75\right.$, and $\left.1.00 \mathrm{~kg} \mathrm{~kg}^{-1}\right)$ in a single-stage mode. DES and model fuel were mixed vigorously for $150 \mathrm{~min}$ (preliminary experiments showed this to be sufficient time for equilibration). The phases were then left to separate in a settling unit at $25^{\circ} \mathrm{C}$ and atmospheric pressure for $24 \mathrm{~h}$.

Raffinate phase compositions after extraction were determined by gas chromatography [GC-2014-Shimadzu / autosampler / FID detector / fused silica capillary column CBP1-S25-050 (length: $25 \mathrm{~m}$, inner diameter: $0.32 \mathrm{~mm}$ ) system]. Extract phase compositions were calculated by mass balance.

\section{Results and discussion}

\subsection{Tie lines in quasi-three-component systems}

The first step in the determination of tie lines is the preparation of calibration curves for the determination of the raffinate phase composition according to Eq. (1). The raffinate phase refractive indices for all the two-component systems ranged from 1.25 to 1.55 and for each system at least 11 data points ( 21 for the toluene systems) were determined, and the correlation coefficients for all systems were at least $R^{2}=0.999$. The calibration curve parameters are shown in Table 3.

Table 3 - Parameters of composition vs. refractive index correlations (Eq. 1)

Tablica 3 - Parametri ovisnosti indeksa loma o sastavu (jedn. 1)

\begin{tabular}{l|r|r|r|r}
\hline \multicolumn{1}{c|}{$\begin{array}{c}\text { System } \\
\text { Sustav }\end{array}$} & A & B & C & $D$ \\
\hline n-hexane (1) - pyridine (2) & 0 & -18.39 & 60.20 & -47.96 \\
n-heptane (1) - pyridine (2) & 220.39 & -978.55 & 1454.93 & -723.50 \\
i-octane (1) - pyridine (2) & 262.15 & -1155.75 & 1705.50 & 841.61 \\
toluene (1) - pyridine (2) & 0 & 0 & 79.73 & -119.09 \\
$n$-hexane (1) - thiophene (2) & 0 & -20.98 & 67.16 & -52.63 \\
$n$-heptane (1) - thiophene (2) & 161.27 & -727.45 & 1098.95 & -555.07 \\
$i$-octane (1) - thiophene (2) & 141.40 & -644.03 & 982.82 & -501.51 \\
toluene (1) - thiophene (2) & 0 & -208.93 & 661.64 & -522.14 \\
\hline
\end{tabular}


The solubility of pyridine or thiophene in DESs is shown in Table 4. The measurement uncertainty here is estimated at a relatively high value of $u(w) \leq 0.01$. Significantly higher solubility of pyridine than thiophene has been observed, which can immediately point to the higher suitability of investigated DESs for denitrification than for desulphurization.

As far as the tie lines in the three-component pyridine systems are concerned, it has already been stated that it was not possible to investigate the entire range of compositions, because the systems with a higher mass fraction of pyridine separated into more than two phases, that is, DESs became unstable. Twelve systems of the hydrocarbon (1) - pyridine (2) - DES (3) type were investigated. Complete experimental data (initial compositions and equilibrium compositions) are available only on request, as supplemental information, due to their extensiveness. Here, the measurement uncertainty is estimated relatively high as well, at $u(w) \leq 0.005$ for initial compositions and for the raffinate phase compositions, and at $u(w) \leq 0.01$ for the extract phase compositions. The graphical representation,

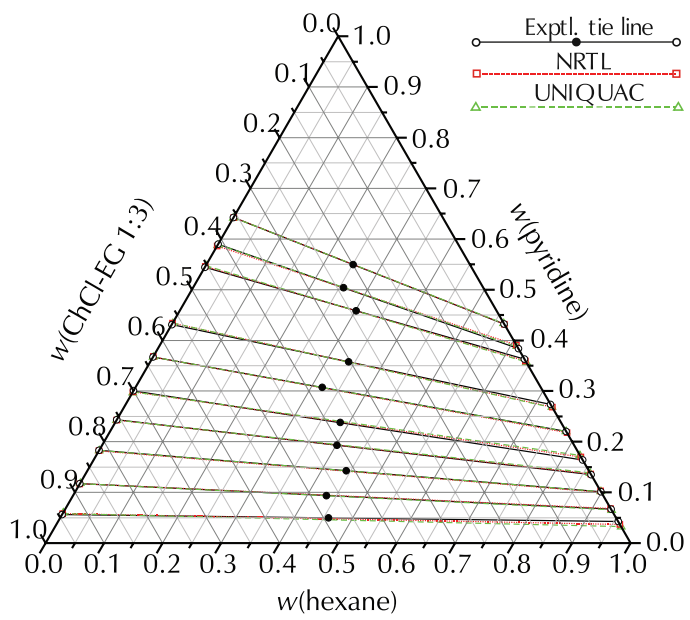

Fig. 1 - Tie lines in the system $n$-hexane (1) - pyridine (2) ChCl-EG 1:3 (3)

Slika 1 - Vezne linije u sustavu $n$-heksan (1) - piridin (2) - ChCl-EG 1:3 (3)

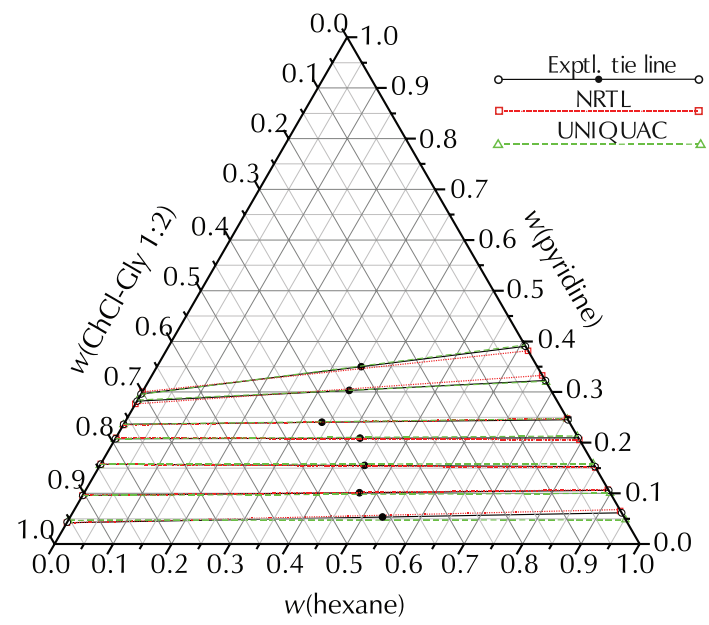

Fig. 3 - Tie lines in the system $n$-hexane (1) - pyridine (2) ChCl-Gly 1:2 (3)

Slika 3 - Vezne linije u sustavu $n$-heksan (1) - piridin (2) - ChCl-Gly 1:2 (3)
Table 4 - Solubility of pyridine or thiophene in investigated DESs at $25^{\circ} \mathrm{C}$

Tablica 4 - Topljivost piridina ili tiofena u istraživanim DES-ovima pri $25{ }^{\circ} \mathrm{C}$

\begin{tabular}{c|c|c}
\hline DES & $\begin{array}{c}\text { Maximal mass fraction } \\
\text { of pyridine } / w_{2} \\
\text { Maksimalni maseni } \\
\text { udjel piridina } / w_{2}\end{array}$ & $\begin{array}{c}\text { Maximal mass fraction } \\
\text { of thiophene } / w_{2} \\
\text { Maksimalni maseni } \\
\text { udjel tiofena } / w_{2}\end{array}$ \\
\hline ChCl-EG 1:2 & 0.630 & 0.092 \\
ChCl-EG 1:3 & 0.746 & 0.102 \\
ChCl-EG 1:3,5 & 0.787 & 0.106 \\
ChCl-Gly 1:1,5 & 0.744 & 0.057 \\
ChCl-Gly $1: 2$ & 0.761 & 0.051 \\
ChCl-Gly $1: 3$ & 0.766 & 0.039
\end{tabular}

i.e. triangular diagrams are shown only for four characteristic systems in Figs. 1-4.

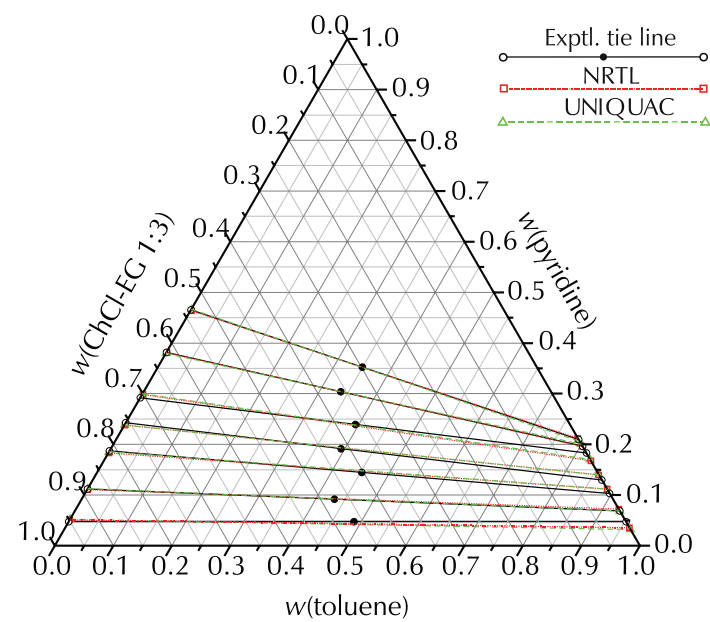

Fig. 2 - Tie lines in the system toluene (1) - pyridine (2) - ChCl-EG 1:3 (3)

Slika 2 - Vezne linije u sustavu toluen (1) - piridin (2) - ChCl-EG $1: 3(3)$

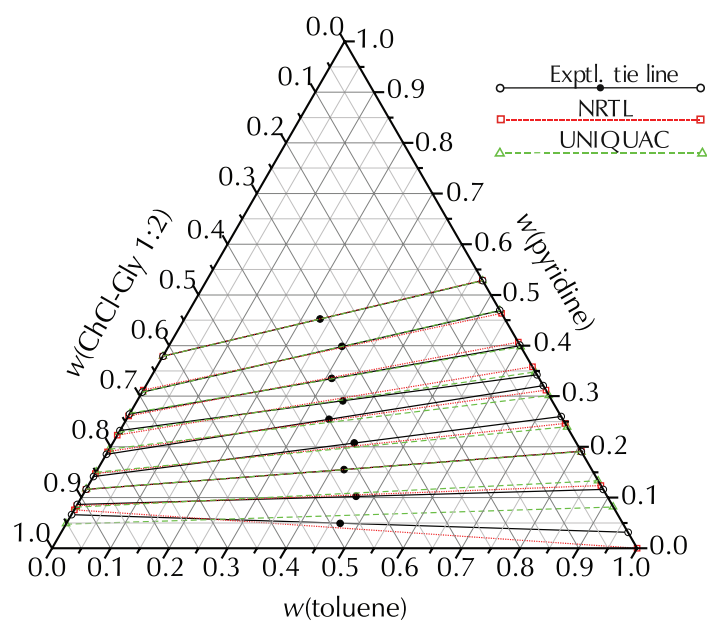

Fig. 4 - Tie lines in the system toluene (1) - pyridine (2) - ChCl-Gly 1:2 (3)

Slika 4 - Vezne linije u sustavu toluen (1) - piridin (2) - ChCl-Gly $1: 2(3)$ 


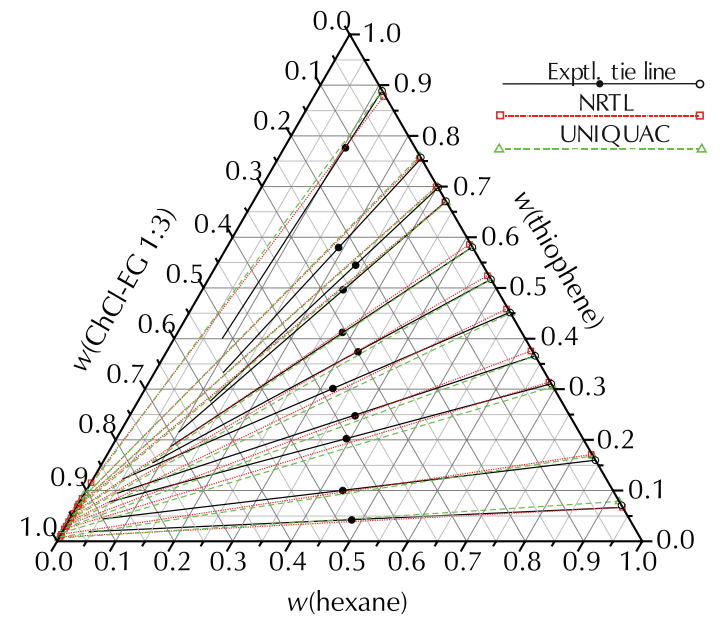

Fig. 5 - Tie lines in the system $n$-hexane (1) - thiophene (2) ChCl-EG 1:3 (3)

Slika 5 - Vezne linije u sustavu $n$-heksan (1) - tiofen (2) - ChCl-EG 1:3 (3)

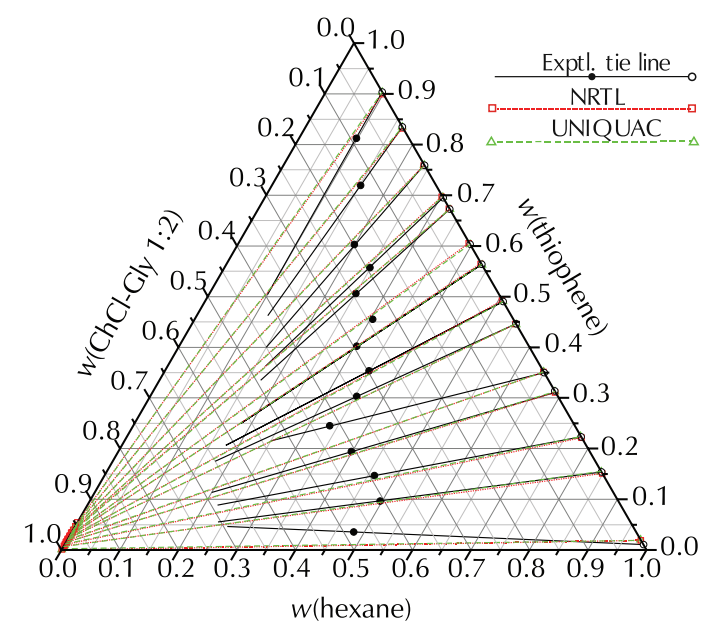

Fig. 7 - Tie lines in the system $n$-hexane (1) - thiophene (2) ChCl-Gly 1:2 (3)

Slika 7 - Vezne linije u sustavu $n$-heksan (1) - tiofen (2) - ChCl-Gly $1: 2(3)$

With respect to tie lines in thiophene systems, the experimental procedure described above proved to be insufficiently precise. Namely, the estimated uncertainty of $u(w) \leq 0.005$ both for the initial composition and the refractive phase was not sufficient to determine the composition of the extract phase with enough certainty by means of the mass balance, due to the relatively high slope of the tie lines, especially at higher thiophene content. Complete experimental data (initial compositions and equilibrium compositions of the raffinate phase) are available only on request, as supplemental information, due to their extensiveness. In Figs. 5-8, only four characteristic systems are shown. The tie lines were not drawn up to the point of the extract phase because some of them would intersect due to the large measurement uncertainty.

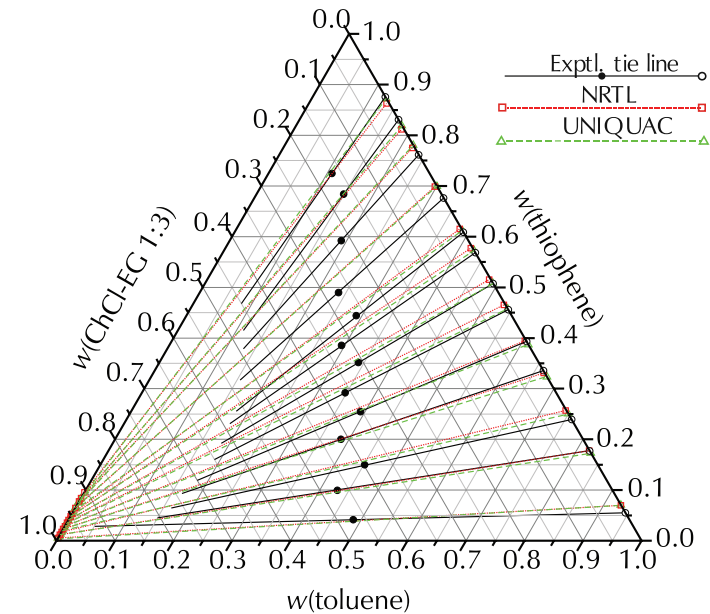

Fig. 6 - Tie lines in the system toluene (1) - thiophene (2) ChCl-EG 1:3 (3)

Slika 6 - Vezne linije u sustavu toluen (1) - tiofen (2) - ChCl-EG $1: 3(3)$

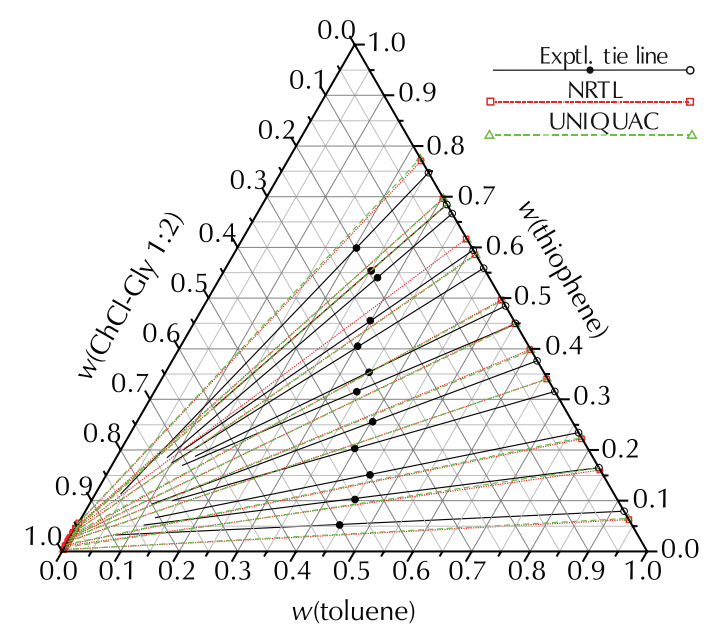

Fig. 8 - Tie lines in the system toluene (1) - thiophene (2) ChCl-Gly $1: 2$ (3)

Slika 8 - Vezne linije u sustavu toluen (1) - tiofen (2) - ChCl-Gly $1: 2(3)$

\subsection{Thermodynamic modelling in quasi-three-component systems}

For describing liquid-liquid phase equilibria in quasi-three-component systems containing DES, NRTL mod$\mathrm{el}^{16,17}$ and COSMO-RS mode $\left.\right|^{16}$ have been used so far; thereby NRTL gave significantly better results.

With respect to our previous studies in systems containing ionic liquids, ${ }^{19,20}$ in this paper we have tried to compare NRTL and UNIQUAC model in their appropriate variants. NRTL model calculates local concentrations of solution components that can be different from global ones due to particle interactions, as described by two interaction energy parameters per pair of molecules or other particles, $\tau_{i j}$ and $\tau_{i j}$. The third, nonrandomness parameter, $\alpha_{i j}=\alpha_{i j}$, is 
introduced to account for other effects. Excess Gibbs energy, $g^{\text {ex }}$, is calculated according to:

$$
g^{\mathrm{ex}} / R T=\sum_{i=1}^{n_{c}} x_{i}\left[\sum_{j=1}^{n_{c}} \tau_{j i} G_{j i} x_{j} / \sum_{k=1}^{n_{c}} G_{k i} x_{k}\right]
$$

with:

$$
G_{i j}=\exp \left(-\alpha_{i j} \tau_{i j}\right)
$$

$n_{c}$ is the number of components (or other particles, e.g. quasi-components) in the system. $\alpha$ parameters are usually fixed at empirical values; here they will be set to the value of 0.3 for all component pairs. ${ }^{10,19,20}$ Interaction parameters are determined by regression from experimental tie line data.

UNIQUAC model takes into account the combinatorial contribution, $g^{\mathrm{ex}, \mathrm{C}}$ which describes the non-ideality of the liquid solution as a result of differences in the size and shape of molecules or of other particles according to:

$$
g^{\mathrm{ex}, \mathrm{C}} /(R T)=\sum_{i=1}^{n_{c}} x_{\mathrm{i}} \ln \left(\Phi_{i} / x_{i}\right)+(z / 2) \sum_{i=1}^{n_{c}} q_{i} x_{i} \ln \left(\Theta_{i} / \Phi_{i}\right)
$$

The residual contribution, $g^{\mathrm{ex}, \mathrm{R}}$, describes the non-ideality as a consequence of interaction of molecules or of other particles according to:

$$
g^{\mathrm{ex}, \mathrm{R}} /(R T)=-\sum_{i=1}^{n_{c}} q_{i} x_{i} \ln \left(\sum_{j=1}^{n_{c}} \Theta_{j} \tau_{j i}\right)
$$

In previous expressions $\Phi_{i}, \Theta_{i}$ and $x_{i}$ denote volume, surface and mole (number) fractions, respectively, of components or any other chemical units, and they are interrelated by the following expressions:

$$
\begin{gathered}
\Phi_{i}=x_{i} r_{i} / \sum_{j=1}^{n_{c}} x_{j} r_{j} \\
\Theta_{i}=x_{i} q_{i} / \sum_{j=1}^{n_{c}} x_{j} q_{j}
\end{gathered}
$$

$r_{i}$ and $q_{i}$ are characteristic volume and surface parameters, respectively, of molecules or any other particles. For most simple substances (hydrocarbons, pyridine and thiophene in this article) they can be calculated by structural group approach according to:

$$
\begin{gathered}
r_{i}=\sum_{k=1}^{n_{\mathrm{g}}} v_{k i} R_{k} \\
q_{i}=\sum_{k=1}^{n_{\mathrm{g}}} v_{k i} Q_{k}
\end{gathered}
$$

using corresponding volume and surface structural group parameters, $R_{k}$ and $Q_{k}$, respectively, which are tabulated in literature. ${ }^{21}$ Different approaches are suggested for other types of particles. In this paper, DESs are treated as qua- si-components and the approach of Domańska ${ }^{22}$ is applied. By that correlation, $r_{i}$ and $q_{i}$ parameters can be related to experimental values of molar volumes of components or, in this case, quasi-components:

$$
\begin{gathered}
r_{i}=0.029281 v_{i} \\
q_{i}=(z-2) r_{i} / z+2\left(1-l_{i}\right) / z
\end{gathered}
$$

Molar volumes are easily calculated from measured system density and the molar mass of the quasi-component. $I_{i}$ is the so-called bulk factor, and here it is assumed to take the value of $0 . z$ is the lattice coordination number and it usually amounts to 10 , both in the expression for $q_{i}$ and in equation for $\mathrm{g}^{\mathrm{ex}, \mathrm{C}}$. The UNIQUAC model parameters used in this paper are listed in Table 5. Interaction parameters $\tau_{i j}$ and $\tau_{i j}$ are determined by regression from experimental tie line data.

Table 5 - UNIQUAC model structure parameters Tablica 5 - Strukturni parametri modela UNIQUAC

\begin{tabular}{lc|c}
\hline \multicolumn{1}{c}{$\begin{array}{c}\text { Component } \\
\text { Komponenta }\end{array}$} & $r$ & $q$ \\
\hline n-hexane & 4.4998 & 3.856 \\
$n$-heptane & 5.1742 & 4.3960 \\
$i$-octane & 5.8463 & 5.0080 \\
toluene & 3.9228 & 2.968 \\
thiophene & 2.8569 & 2.140 \\
pyridine & 2.9993 & 2.113 \\
ChCl-EG 1 :2 & 6.859 & 5.687 \\
ChCl-EG 1:3 & 8.487 & 6.990 \\
ChCl-EG 1:3.5 & 9.304 & 7.643 \\
ChCl-Gly 1:1.5 & 6.841 & 5.673 \\
ChCl-Gly 1:2 & 7.897 & 6.518 \\
ChCl-Gly 1:3 & 10.079 & 8.263
\end{tabular}

\subsection{Interaction parameters in quasi-three component systems with pyridine}

The regression procedure for both models in this part is virtually identical to that described in our previous works. ${ }^{19,20}$ A modified Sørensen-Arlt procedure is used; in the first step, the minimum of the following function is searched for:

$$
\begin{aligned}
O F_{1} & =\sum_{j=1}^{n_{d}} \sum_{i=1}^{n_{c}}\left[\left(x_{i}^{\mathrm{R}} \gamma_{i}^{\mathrm{R}}-x_{i}^{\mathrm{E}} \gamma_{i}^{\mathrm{E}}\right) /\left(x_{i}^{\mathrm{R}} \gamma_{i}^{\mathrm{R}}+x_{i}^{\mathrm{E}} \gamma_{i}^{\mathrm{E}}\right)\right]_{j}^{2}+ \\
& +Q\left(\tau_{12}^{2}+\tau_{21}^{2}+\tau_{13}^{2}+\tau_{31}^{2}+\tau_{23}^{2}+\tau_{32}^{2}\right)
\end{aligned}
$$

with respect to six interaction parameters $\tau_{i j}$ using fixed values of nonrandomness parameters $\alpha_{i j}=0.3 . \gamma_{i}$ are the activity coefficients; the expressions for $\gamma_{i}$ are obtained by differentiating the appropriate expressions for the excess Gibbs energy and can be found elsewhere. ${ }^{23} n_{\mathrm{c}}=3$ is the number of components and quasi-components, and $n_{d}$ is the number of experimental tie lines. The so-called penalty function is set to $Q=1 \times 10^{-6}$ for both models ${ }^{10}$ and 
serves to reject unrealistically large $\tau$-values which might produce local minima of $O F_{1}$.

Calculated interaction parameters serve as an initiation for the second step, where the minimum of the following function is searched for:

$$
\begin{gathered}
O F_{2}=\sum_{j=1}^{n_{d}} \sum_{i=1}^{n_{c}} \sum_{p=R, \mathrm{E}}\left[\left(w_{i}^{p}\right)_{\exp }-\left(w_{i}^{p}\right)_{\bmod }\right]_{j}^{2}+ \\
+Q\left(\tau_{12}^{2}+\tau_{21}^{2}+\tau_{13}^{2}+\tau_{31}^{2}+\tau_{23}^{2}+\tau_{32}^{2}\right)
\end{gathered}
$$

aiming at producing the best possible match of experimental equilibrium compositions. The penalty function value here is set to $Q=1 \times 10^{-10}$ for both models. ${ }^{10} W_{i}$ are the mass fractions of the components (which is the difference compared to the original Sørensen-Arlt method that defines the function over molar ratios). $p=\mathrm{R}$ and $p=\mathrm{E}$ denote raffinate and extract phase, respectively.
The optimal model parameters are shown in Table 6, together with the average absolute prediction errors of equilibrium mass fractions as calculated by:

$$
\begin{aligned}
& A= \\
& \sqrt{\left[O F_{2}-Q\left(\tau_{12}^{2}+\tau_{21}^{2}+\tau_{13}^{2}+\tau_{31}^{2}+\tau_{23}^{2}+\tau_{32}^{2}\right)\right] /\left(n_{d} \cdot n_{c} \cdot 2\right)}(14)
\end{aligned}
$$

Equilibrium compositions calculated using the models are compared to experimental ones and they are shown for selected systems in Figs. 1-4. The agreement can be considered rather good, based on low A-values obtained. By comparing interaction parameters of individual systems, certain regularities were observed that would be taken into account later when extrapolating data to other systems. The calculated equilibrium compositions for all systems are available only on request as supplemental information, due to their extensiveness.

Table 6 - Optimal NRTL and UNIQUAC model interaction parameters and average absolute prediction errors for the pyridine-con-

\begin{tabular}{|c|c|c|c|c|c|c|c|}
\hline NRTL $\alpha_{12} ; \alpha_{13} ; \alpha_{23}=0.3 ; 0.3 ; 0.3$ & $\tau_{12}$ & $\tau_{13}$ & $\tau_{21}$ & $\tau_{23}$ & $\tau_{31}$ & $\tau_{32}$ & A \\
\hline$n$-hexane (1) - pyridine (2) - ChCl-EG 1:2 (3) & 1.4938 & 12.4133 & 8.9182 & 13.5841 & 9.8920 & 0.8335 & 0.0054 \\
\hline$n$-heptane (1) - pyridine (2) - ChCl-EG 1:2 (3) & $0.0297^{*}$ & 19.3031 & 7.8438 & 19.3636 & 9.1566 & $-0.7028^{*}$ & 0.0052 \\
\hline i-octane (1) - pyridine (2) - ChCl-EG 1:2 (3) & 0.7280 & 15.0908 & 6.3910 & 14.8661 & 13.6420 & 1.3190 & 0.0029 \\
\hline toluene (1) - pyridine (2) - ChCl-EG 1:2 (3) & $0.1445^{*}$ & 11.0991 & 5.8003 & 16.5042 & 9.4131 & 1.1202 & 0.0071 \\
\hline n-hexane (1) - pyridine (2) - ChCl-EG 1:3 (3) & 1.7119 & 18.7921 & 10.3059 & 18.6398 & 7.0916 & 0.4363 & 0.0027 \\
\hline n-heptane (1) - pyridine (2) - ChCl-EG 1:3 (3) & 1.0741 & 14.2729 & 7.9995 & 15.9081 & 5.2913 & $-0.2533^{*}$ & 0.0054 \\
\hline i-octane (1) - pyridine (2) - ChCl-EG 1:3 (3) & 1.2821 & 21.6590 & 8.5159 & 19.2138 & 7.9995 & 1.0606 & 0.0049 \\
\hline toluene (1) - pyridine (2) - ChCl-EG 1:3 (3) & $1.3687^{*}$ & 14.0906 & 5.1349 & 8.7051 & 15.5565 & $0.2939^{*}$ & 0.0057 \\
\hline$n$-hexane (1) - pyridine (2) - ChCl-EG 1:3.5 (3) & 2.0993 & 19.3546 & 8.2701 & 11.5739 & 5.4768 & 1.0061 & 0.0036 \\
\hline n-heptane (1) - pyridine (2) - ChCl-EG 1:3.5 (3) & 1.5488 & 18.2480 & 7.8869 & 12.9789 & 11.1737 & $14.9702^{*}$ & 0.0040 \\
\hline i-octane (1) - pyridine (2) - ChCl-EG 1:3.5 (3) & 1.5483 & 24.7799 & 8.9062 & 18.1421 & 6.9045 & 1.2557 & 0.0057 \\
\hline toluene (1) - pyridine (2) - ChCl-EG 1:3.5 (3) & $1.3075^{*}$ & 13.8464 & 5.0101 & 8.7253 & 15.4801 & 1.6839 & 0.0067 \\
\hline n-hexane (1) - pyridine (2) - ChCl-Gly 1:1.5 (3) & 2.2566 & 14.9139 & 12.0938 & 13.3919 & 12.3707 & 2.2505 & 0.0099 \\
\hline n-heptane (1) - pyridine (2) - ChCl-Gly 1:1.5 (3) & 1.9382 & 14.5587 & 12.0775 & 13.6596 & 12.3867 & 0.7656 & 0.0096 \\
\hline i-octane (1) - pyridine (2) - ChCl-Gly 1:1.5 (3) & 1.1168 & 15.5462 & 11.2275 & 15.0223 & 11.8542 & 1.4458 & 0.0028 \\
\hline toluene (1) - pyridine (2) - ChCl-Gly 1:1.5 (3) & 11.9978 & 19.7290 & 8.7013 & 15.9875 & 32.6193 & 1.0081 & 0.0107 \\
\hline n-hexane (1) - pyridine (2) - ChCl-Gly 1:2 (3) & 2.1774 & 8.1347 & 9.8881 & 11.6690 & 12.9617 & 1.7835 & 0.0037 \\
\hline n-heptane (1) - pyridine (2) - ChCl-Gly 1:2 (3) & 2.0920 & 8.2722 & 10.0840 & 11.7431 & 13.2568 & 1.4582 & 0.0089 \\
\hline i-octane (1) - pyridine (2) - ChCl-Gly 1:2 (3) & 1.9229 & 14.4350 & 10.6853 & 13.8492 & 12.6237 & 2.1945 & 0.0030 \\
\hline toluene (1) - pyridine (2) - ChCl-Gly 1:2 (3) & 12.3460 & 20.1972 & 11.3394 & 14.8723 & 32.4246 & $-0.4306^{*}$ & 0.0084 \\
\hline n-hexane (1) - pyridine (2) - ChCl-Gly 1:3 (3) & 0.7578 & 5.2734 & $2.5079^{*}$ & 11.7239 & 6.5733 & $-1.2651^{*}$ & 0.0091 \\
\hline n-heptane (1) - pyridine (2) - ChCl-Gly 1:3 (3) & 0.9317 & 5.4217 & $1.8711^{*}$ & 15.7645 & 7.7945 & 0.8885 & 0.0124 \\
\hline i-octane (1) - pyridine (2) - ChCl-Gly 1:3 (3) & $-0.0685^{*}$ & 4.5201 & $2.7072^{*}$ & 17.8930 & 5.9000 & $-1.5744^{*}$ & 0.0108 \\
\hline toluene (1) - pyridine (2) - ChCl-Gly 1:3 (3) & 13.3033 & 18.4480 & 11.2062 & 16.9567 & 33.8312 & $-0.6163^{*}$ & 0.0104 \\
\hline
\end{tabular}
taining systems studied

Tablica 6 - Optimalni interakcijski parametri modela NRTL i UNIQUAC i srednja kvadratna odstupanja od predviđanja za istraživane sustave s piridinom 
Table 6 - (continued)

Tablica 6 - (nastavak)

\begin{tabular}{|c|c|c|c|c|c|c|c|}
\hline UNIQUAC & $\tau_{12}$ & $\tau_{13}$ & $\tau_{21}$ & $\tau_{23}$ & $\tau_{31}$ & $\tau_{32}$ & $A$ \\
\hline n-hexane (1) - pyridine (2) - ChCl-EG 1:2 (3) & 1.6374 & 0.2165 & 0.0755 & 0.0093 & 0.0632 & 3.0117 & 0.0058 \\
\hline n-heptane (1) - pyridine (2) - ChCl-EG 1:2 (3) & 1.0171 & $0.0650^{*}$ & 0.2688 & 0.0011 & $0.0121^{*}$ & 2.1551 & 0.0035 \\
\hline i-octane (1) - pyridine (2) - ChCl-EG 1:2 (3) & 1.6856 & 0.7864 & $0.0061^{*}$ & $0.6457^{*}$ & 0.2730 & 1.3489 & 0.0082 \\
\hline toluene (1) - pyridine (2) - ChCl-EG 1:2 (3) & 1.2933 & 0.1855 & 0.0140 & $0.7069^{*}$ & 0.0058 & 0.7201 & 0.0025 \\
\hline n-hexane (1) - pyridine (2) - ChCl-EG 1:3 (3) & $2.3526^{*}$ & $0.0547^{*}$ & 0.0285 & $0.7191^{*}$ & $0.4595^{*}$ & 2.4625 & 0.0033 \\
\hline n-heptane (1) - pyridine (2) - ChCl-EG 1:3 (3) & 0.9787 & $0.0128^{*}$ & 0.3898 & 0.0859 & $0.7068^{*}$ & 2.6309 & 0.0052 \\
\hline i-octane (1) - pyridine (2) - ChCl-EG 1:3 (3) & 1.6759 & 0.4115 & 0.0184 & $0.5819^{*}$ & 0.1698 & 1.7041 & 0.0060 \\
\hline toluene (1) - pyridine (2) - ChCl-EG 1:3 (3) & 0.6160 & 0.0184 & 0.2603 & 0.0418 & 0.1876 & 1.5621 & 0.0054 \\
\hline n-hexane (1) - pyridine (2) - ChCl-EG 1:3.5 (3) & 1.5667 & 0.6317 & 0.1577 & $3.6030^{*}$ & 0.0840 & $0.0022^{*}$ & 1.5667 \\
\hline n-heptane (1) - pyridine (2) - ChCl-EG 1:3.5 (3) & 0.5267 & $0.0331^{*}$ & 0.6659 & 0.0078 & 0.1418 & 2.2502 & 0.5267 \\
\hline i-octane (1) - pyridine (2) - ChCl-EG 1:3.5 (3) & 1.7022 & 0.3966 & 0.0341 & $0.3622^{*}$ & 0.1327 & 2.3550 & 1.7022 \\
\hline toluene (1) - pyridine (2) - ChCl-EG 1:3.5 (3) & 1.1534 & 0.0711 & 0.2098 & $1.8057^{*}$ & 0.0656 & $0.2228^{*}$ & 1.1534 \\
\hline n-hexane (1) - pyridine (2) - ChCl-Gly 1:1.5 (3) & 0.8788 & 0.0668 & 0.1234 & 0.0147 & 0.0380 & 1.2029 & 0.0102 \\
\hline n-heptane (1) - pyridine (2) - ChCl-Gly 1:1.5 (3) & 0.5833 & 0.0697 & 0.7473 & 0.0377 & 0.0523 & 1.9962 & 0.0037 \\
\hline i-octane (1) - pyridine (2) - ChCl-Gly 1:1.5 (3) & 0.5256 & 0.0025 & 1.1915 & $1.7811^{*}$ & 0.0329 & $0.2580^{*}$ & 0.0024 \\
\hline toluene (1) - pyridine (2) - ChCl-Gly 1:1.5 (3) & 1.7363 & 0.0008 & $0.0008^{*}$ & $0.5214^{*}$ & $0.0009^{*}$ & 1.0372 & 0.0131 \\
\hline n-hexane (1) - pyridine (2) - ChCl-Gly 1:2 (3) & 0.6886 & 0.4331 & 0.3674 & 0.0120 & 0.0580 & 1.5316 & 0.0036 \\
\hline n-heptane (1) - pyridine (2) - ChCl-Gly 1:2 (3) & 0.7430 & 0.5701 & 0.5097 & 0.0362 & 0.0700 & 1.8564 & 0.0017 \\
\hline i-octane (1) - pyridine (2) - ChCl-Gly 1:2 (3) & 0.8054 & 0.7658 & 0.4650 & 0.0719 & 0.1804 & 1.7658 & ** \\
\hline toluene (1) - pyridine (2) - ChCl-Gly 1:2 (3) & 1.0249 & 0.2680 & 0.0042 & 0.0925 & 0.0730 & 1.1876 & 0.0121 \\
\hline n-hexane (1) - pyridine (2) - ChCl-Gly 1:3 (3) & 0.5560 & 0.1037 & 0.8760 & 0.0034 & 0.0129 & 3.1512 & 0.0061 \\
\hline n-heptane (1) - pyridine (2) - ChCl-Gly $1: 3$ (3) & 0.6098 & 0.0786 & 0.7058 & 0.0029 & 0.0136 & 2.5666 & 0.0061 \\
\hline i-octane (1) - pyridine (2) - ChCl-Gly 1:3 (3) & 0.9298 & 0.0309 & 0.7329 & 0.0245 & 0.2601 & 3.9091 & 0.0068 \\
\hline toluene (1) - pyridine (2) - ChCl-Gly $1: 3$ (3) & 1.9656 & 0.6037 & 0.0313 & 0.1128 & 0.0557 & 2.1961 & 0.0116 \\
\hline
\end{tabular}

* outlying values not used for subsequent averaging / stršeće vrijednosti koje nisu primijenjene za naknadno uprosječivanje

${ }^{* *}$ for this system, the second best set of parameters was used due to a better accordance with other systems / za ovaj je sustav odabran drugi najbolji

skup parametara zbog boljega slaganja s ostalim sustavima

\subsection{Interaction parameters in quasi-three component systems with thiophene}

As already mentioned, using the described experimental procedure a thermodynamically consistent set of tie lines could not be obtained, from which the interaction parameters would be determined. Nevertheless, the literature describes the possibilities of determining interaction parameters based on a limited set of experimental data, with the extrapolation of part of information from other systems, or other models. Thus, ChemCAD chemical-engineering simulation software by Chemstations ${ }^{\text {TM }}$ offers an estimation of the interaction parameters of the NRTL and UNIQUAC models based on the Gibbs energy vs. composition dependence simulated by the UNIFAC model. This option is default in two-component systems in which there are no corresponding experimental data on vapour-liquid equilib- rium. This de facto means that data from related systems are extrapolated to the one currently under consideration.

Following this idea, an extrapolation procedure for determining the interaction parameters in the thiophene system was constructed. Three assumptions were taken into consideration. The first is that the interaction parameters already determined from the experimental data in the pyridine systems could be carried over to the thiophene systems, which both NRTL and UNIQUAC models provide in principle. Prior to transferring, the interaction parameters (from Table 6) were averaged wherever possible, rejecting the outlying values (marked with an asterisk in Table 6). Secondly, it was assumed that the interaction parameters of all three aliphatic hydrocarbons to other components of the system (ionic liquid or pyridine) are equal, which is the "natural" assumption of the UNIQUAC mod- 
el; in the NRTL model it is not a "natural" assumption, but merely the regularity observed in the previous calculations (see Table 6) is taken into account. Here, only the parameters of the interaction of hydrocarbons with ionic liquid are relevant for transferring into thiophene systems; those describing hydrocarbon/pyridine interactions will be important later when transferring to quasi-seven-component systems. Thirdly, the previous experiments confirmed the complete immiscibility of the investigated DESs with all the hydrocarbons; additional experiments determined the mutual solubility of thiophene and all explored DESs. Therefrom it was possible to generate a set of extract phase compositions equidistantly distributed between the point of pure DES and the point of maximum thiophene solubility in DES (in the triangular diagram). Because of the low solubility of thiophene in all explored DESs, the extract phase compositions thus generated could not differ significantly from the true compositions of the extract phase. In other words, they could very probably be within the experimental error of some better method for the equilibrium composition determination, e.g. ${ }^{1} \mathrm{H}$ NMR as described in the literature. ${ }^{16}$ Further on, a set of tie lines linking the actual, experimentally determined raffinate phase compositions and generated extract phase compositions could be formed.

After generating a set of tie lines, the interaction parameters were determined in a manner analogous to that described in the previous section. Since the parameters related to the hydrocarbon/DES interactions, $\tau_{13}$ and $\tau_{31}$ were fixed based on previous calculations, the remaining four parameters were optimized, and the objective functions in the first and second step of the modified Sørensen-Arlt procedure were:

$$
\begin{aligned}
O F_{3}=\sum_{j=1}^{n_{d}} \sum_{i=1}^{n_{c}}\left[\left(x_{i}^{\mathrm{R}} \gamma_{i}^{\mathrm{R}}-x_{i}^{\mathrm{E}} \gamma_{i}^{\mathrm{E}}\right) /\left(x_{i}^{\mathrm{R}} \gamma_{i}^{\mathrm{R}}+x_{i}^{\mathrm{E}} \gamma_{i}^{\mathrm{E}}\right)\right]_{j}^{2}+ \\
+Q\left(\tau_{12}^{2}+\tau_{21}^{2}+\tau_{23}^{2}+\tau_{32}^{2}\right) \\
O F_{4}=\sum_{j=1}^{n_{d}} \sum_{i=1}^{n_{c}} \sum_{p=R, \mathrm{E}}\left[\left(w_{i}^{p}\right)_{\exp }-\left(w_{i}^{p}\right)_{\bmod }\right]_{j}^{2}+ \\
+Q\left(\tau_{12}^{2}+\tau_{21}^{2}+\tau_{23}^{2}+\tau_{32}^{2}\right)
\end{aligned}
$$

Since the tie lines obtained by the model were not compared with the experimental ones but rather with those generated on the basis of the several assumptions described, it made no sense to define average absolute prediction errors in the manner described in Eq. (14).

The optimum model parameters are shown in Table 7. The tie lines calculated using the model are compared to the experimental findings in selected systems, as shown in Figs. 5-8. Comparison of the interaction parameters between individual systems also shows certain regularities that will be taken into account when extrapolating the data to other systems. The calculated equilibrium compositions for all systems are available only on request as supplemen-

\begin{tabular}{|c|c|c|c|c|c|c|}
\hline NRTL $\alpha_{12} ; \alpha_{13} ; \alpha_{23}=0.3 ; 0.3 ; 0.3$ & $\tau_{12}$ & $\tau_{13}^{*}$ & $\tau_{21}$ & $\tau_{23}$ & $\tau_{31}^{*}$ & $\tau_{32}$ \\
\hline$n$-hexane (1) - thiophene (2) - ChCl-EG 1:2 (3) & 14.7027 & 15.6024 & 18.3542 & 5.7708 & 10.8969 & 0.8495 \\
\hline$n$-heptane (1) - thiophene (2) - ChCl-EG 1:2 (3) & 14.5569 & 15.6024 & 18.2657 & 5.9139 & 10.8969 & 1.0641 \\
\hline i-octane (1) - thiophene (2) - ChCl-EG 1:2 (3) & 14.5583 & 15.6024 & 18.2083 & 5.8257 & 10.8969 & 0.9597 \\
\hline toluene (1) - thiophene (2) - ChCl-EG 1:2 (3) & 14.5816 & 14.0906 & 18.1939 & 5.7809 & 9.4131 & 0.8685 \\
\hline n-hexane (1) - thiophene (2) - ChCl-EG 1:3 (3) & 12.3085 & 18.2413 & 15.2669 & 5.8084 & 6.7942 & 0.6283 \\
\hline n-heptane (1) - thiophene (2) - ChCl-EG 1:3 (3) & 14.5842 & 18.2413 & 18.2904 & 5.7469 & 6.7942 & 0.6057 \\
\hline$i$-octane $(1)$ - thiophene (2) - ChCl-EG 1:3 (3) & 13.2086 & 18.2413 & 23.8682 & 5.8753 & 6.7942 & 0.6410 \\
\hline toluene (1) - thiophene (2) - ChCl-EG 1:3 (3) & 14.6474 & 11.0991 & 18.2144 & 5.7991 & 15.5565 & 0.6563 \\
\hline$n$-hexane (1) - thiophene (2) - ChCl-EG 1:3.5 (3) & 14.6657 & 20.7942 & 18.2990 & 6.3105 & 7.8517 & 0.4754 \\
\hline n-heptane (1) - thiophene (2) - ChCl-EG 1:3.5 (3) & 14.6638 & 20.7942 & 18.1966 & 6.1026 & 7.8517 & 0.6398 \\
\hline$i$-octane (1) - thiophene (2) - ChCl-EG 1:3.5 (3) & 14.8939 & 20.7942 & 24.0836 & 6.1000 & 7.8517 & 0.5731 \\
\hline toluene (1) - thiophene (2) - ChCl-EG 1:3.5 (3) & 14.5782 & 13.8464 & 18.1906 & 6.0580 & 15.4801 & 0.4949 \\
\hline n-hexane (1) - thiophene (2) - ChCl-Gly 1:1.5 (3) & 0.7461 & 15.0063 & 14.7423 & 6.3765 & 12.2039 & 1.5503 \\
\hline$n$-heptane (1) - thiophene (2) - ChCl-Gly $1: 1.5$ (3) & 0.0958 & 15.0063 & 14.9081 & 7.2515 & 12.2039 & 1.8053 \\
\hline i-octane (1) - thiophene (2) - ChCl-Gly 1:1.5 (3) & 0.3501 & 15.0063 & 14.7983 & 6.3174 & 12.2039 & 1.6961 \\
\hline toluene (1) - thiophene (2) - ChCl-Gly 1:1.5 (3) & 0.7247 & 19.7290 & 13.4731 & 7.0417 & 32.6193 & 1.7603 \\
\hline
\end{tabular}
tary information, due to their extensiveness.

Table 7 - Optimal NRTL and UNIQUAC model interaction parameters

Tablica 7 - Optimalni interakcijski parametri modela NRTL i UNIQUAC 
Table 7 - (continued)

Tablica 7 - (nastavak)

\begin{tabular}{|c|c|c|c|c|c|c|}
\hline NRTL $\alpha_{12} ; \alpha_{13} ; \alpha_{23}=0.3 ; 0.3 ; 0.3$ & $\tau_{12}$ & $\tau_{13}^{*}$ & $\tau_{21}$ & $\tau_{23}$ & $\tau_{31}^{*}$ & $\tau_{32}$ \\
\hline$n$-hexane (1) - thiophene (2) - ChCl-Gly 1:2 (3) & 0.8256 & 10.2806 & 14.8034 & 6.3475 & 12.9474 & 1.5913 \\
\hline n-heptane (1) - thiophene (2) - ChCl-Gly $1: 2$ (3) & 0.5778 & 10.2806 & 14.5707 & 6.1912 & 12.9474 & 1.4147 \\
\hline i-octane (1) - thiophene (2) - ChCl-Gly 1:2 (3) & 0.4962 & 10.2806 & 15.3825 & 6.7704 & 12.9474 & 1.6624 \\
\hline toluene (1) - thiophene (2) - ChCl-Gly 1:2 (3) & 0.7574 & 20.1972 & 13.4993 & 7.0997 & 32.4246 & 1.6525 \\
\hline n-hexane (1) - thiophene (2) - ChCl-Gly 1:3 (3) & 1.0107 & 5.0717 & 15.9117 & 6.9515 & 6.7559 & 1.7216 \\
\hline n-heptane (1) - thiophene (2) - ChCl-Gly $1: 3$ (3) & 0.4921 & 5.0717 & 16.0278 & 7.5559 & 6.7559 & 1.9789 \\
\hline i-octane (1) - thiophene (2) - ChCl-Gly 1:3 (3) & 0.6477 & 5.0717 & 15.3116 & 8.1445 & 6.7559 & 2.0653 \\
\hline toluene (1) - thiophene (2) - ChCl-Gly 1:3 (3) & 0.7167 & 18.4480 & 13.6023 & 7.0666 & 33.8312 & 1.7879 \\
\hline UNIQUAC & $\tau_{12}$ & $\tau_{13}$ & $\tau_{21}$ & $\tau_{23}$ & $\tau_{31}$ & $\tau_{32}$ \\
\hline n-hexane (1) - thiophene (2) - ChCl-EG 1:2 (3) & 2.1182 & 0.5015 & 0.2417 & 0.0259 & 0.1681 & 1.1720 \\
\hline n-heptane (1) - thiophene (2) - ChCl-EG 1:2 (3) & 2.3845 & 0.5015 & 0.2729 & 0.0333 & 0.1681 & 1.1613 \\
\hline i-octane (1) - thiophene (2) - ChCl-EG 1:2 (3) & 2.6330 & 0.5015 & 0.1242 & 0.0403 & 0.1681 & 1.1423 \\
\hline toluene (1) - thiophene (2) - ChCl-EG 1:2 (3) & 2.3133 & 0.1855 & 0.1670 & 0.0867 & 0.0058 & 1.0833 \\
\hline$n$-hexane (1) - thiophene (2) - ChCl-EG 1:3 (3) & 2.2831 & 0.4115 & 0.1769 & 0.0457 & 0.1698 & 1.2340 \\
\hline n-heptane (1) - thiophene (2) - ChCl-EG 1:3 (3) & 1.9542 & 0.4115 & 0.3132 & 0.0995 & 0.1698 & 1.1472 \\
\hline i-octane (1) - thiophene (2) - ChCl-EG 1:3 (3) & $0.3472^{*}$ & 0.4115 & $2.0102^{*}$ & 0.0847 & 0.1698 & 1.1702 \\
\hline toluene (1) - thiophene (2) - ChCl-EG 1:3 (3) & 2.2937 & 0.0184 & 0.1872 & 0.0446 & 0.1876 & 1.1844 \\
\hline$n$-hexane (1) - thiophene (2) - ChCl-EG 1:3.5 (3) & 2.0358 & 0.5142 & 0.2567 & 0.1111 & 0.1195 & 1.1711 \\
\hline n-heptane (1) - thiophene (2) - ChCl-EG 1:3.5 (3) & 2.3546 & 0.5142 & 0.2517 & 0.1317 & 0.1195 & 1.1426 \\
\hline i-octane (1) - thiophene (2) - ChCl-EG 1:3.5 (3) & 1.3551 & 0.5142 & 0.7296 & 0.2198 & 0.1195 & 1.0214 \\
\hline toluene (1) - thiophene (2) - ChCl-EG 1:3.5 (3) & 1.8410 & 0.0711 & 0.3755 & 0.0395 & 0.0656 & 1.2851 \\
\hline n-hexane (1) - thiophene (2) - ChCl-Gly 1:1.5 (3) & 2.1668 & 0.0463 & 0.2143 & 0.0754 & 0.0411 & 0.9304 \\
\hline n-heptane (1) - thiophene (2) - ChCl-Gly 1:1.5 (3) & 3.3305 & 0.0463 & 0.0141 & 0.1570 & 0.0411 & 0.8455 \\
\hline i-octane (1) - thiophene (2) - ChCl-Gly 1:1.5 (3) & 2.8232 & 0.0463 & 0.0861 & 0.1358 & 0.0411 & 0.8430 \\
\hline toluene (1) - thiophene (2) - ChCl-Gly 1:1.5 (3) & 2.5909 & 0.0008 & 0.0803 & 0.0301 & 0.0009 & 0.9794 \\
\hline n-hexane (1) - thiophene (2) - ChCl-Gly 1:2 (3) & 2.3193 & 0.5896 & 0.1822 & 0.0184 & 0.1028 & 0.9592 \\
\hline$n$-heptane (1) - thiophene (2) - ChCl-Gly $1: 2$ (3) & 2.5264 & 0.5896 & 0.0391 & 0.1016 & 0.1028 & 0.8618 \\
\hline$i$-octane (1) - thiophene (2) - ChCl-Gly $1: 2$ (3) & 2.9453 & 0.5896 & 0.0482 & 0.0909 & 0.1028 & 0.8868 \\
\hline toluene (1) - thiophene (2) - ChCl-Gly 1:2 (3) & 2.5994 & 0.2680 & 0.0620 & 0.0353 & 0.0730 & 0.9922 \\
\hline n-hexane (1) - thiophene (2) - ChCl-Gly 1:3 (3) & 2.1066 & 0.0711 & 0.2979 & 0.1367 & 0.0955 & 0.7965 \\
\hline$n$-heptane (1) - thiophene (2) - ChCl-Gly 1:3 (3) & $0.0801^{*}$ & 0.0711 & $3.1883^{*}$ & $0.2152^{*}$ & 0.0955 & $0.7237^{*}$ \\
\hline i-octane (1) - thiophene (2) - ChCl-Gly 1:3 (3) & 3.1802 & 0.0711 & 0.0392 & 0.1394 & 0.0955 & 0.7892 \\
\hline toluene (1) - thiophene (2) - ChCl-Gly 1:3 (3) & 2.7467 & 0.6037 & 0.0492 & 0.0250 & 0.0557 & 0.8774 \\
\hline
\end{tabular}

* fixed values averaged from the pyridine-containing systems

"fiksne vrijednosti dobivene uprosječivanjem iz sustava s piridinom 


\subsection{Extraction experiments in quasi-seven-component systems}

The quasi-seven-component systems are obtained by mixing pre-prepared samples of model FCC-gasoline with DESs in different ratios. Components of the solutions were enumerated as: $n$-hexane $-1, n$-heptane -2 , i-octane -3 , toluene -4 , thiophene -5 , pyridine -6 , DES -7 . The solution compositions were determined by weighing and the measurement uncertainty was estimated at $u(w) \leq 0.001$. The raffinate phase compositions were determined by the gas-chromatographic method, and the measurement uncertainty was estimated at $u(w) \leq 0.01$. The presence of DES in the raffinate phase was not observed, so the mass fraction was set to a low value, $w_{7}^{\mathrm{R}} \leq 1 \times 10^{-6}$. Compositions of the extract phase were calculated from the mass balance as follows. It was assumed that the extract phase contained practically all DES and no aliphatic hydrocarbons, i.e. the mass fraction of aliphatic hydrocarbons in the extract stage was set at $w_{i}{ }^{E}=1 \times 10^{-6}$. The mass fraction of the raffinate phase, $\Psi^{R}$, was calculated according to:

$$
\Psi^{\mathrm{R}}=\left(w_{i}^{\mathrm{F}}-w_{i}^{\mathrm{E}}\right) /\left(w_{i}^{\mathrm{R}}-w_{i}^{\mathrm{E}}\right)
$$

where $i$ denotes the component, and the superscripts $F$, $\mathrm{E}, \mathrm{R}$ denote the total mixture, the extract phase and the refractive phase, respectively. For each hydrocarbon, a distinct value of $\Psi^{R}$ was obtained; the appropriate value for the whole system was calculated as the average of the three specific individual values. Subsequently, the mass fractions of the extractable components (toluene, thiophene and pyridine) and DES were calculated according to:

$$
w_{i}^{\mathrm{E}}=\left(w_{i}^{\mathrm{F}}-\psi^{\mathrm{R}} w_{i}^{\mathrm{R}}\right) /\left(1-\psi^{\mathrm{R}}\right)
$$

Mass fractions in both phases were then normalized to the sum of 1 . The procedure was repeated for all six investigated DESs and for each of the four different mass ratios of DES / model fuel. Because of their extensiveness, the results are presented in tables as supplemental information. The graphs are included here only to compare the experimental values to those obtained from the NRTL and UNIQUAC models, Figs. 9-12, as an illustration of the possibilities and limitations in the description of the investigated systems by thermodynamic models. The discussion of the quality of the DESs as extraction media will be the subject of future publications.

\subsection{Extraction experiments in quasi-seven-component systems}

The approach described in our previous papers ${ }^{19,20}$ showed that it is possible, not only in principle, to transfer the parameters from three-component systems into seven-component systems, and that it is possible to obtain a satisfactory quantitative description of the separation of an unstable system into two stable equilibrium phases in the thermodynamic equilibrium in the case of extraction of nitrogen-containing, sulphur-containing and aromatic components from model solutions mimicking FCC-gasoline.
A similar procedure was used in this paper in order to transfer the parameters determined in quasi-three-component systems into quasi-seven-component ones, by generating tables of parameters such as that shown in Table 8. Thereby, binary parameters describing interaction of low molecular components that were not determined by experiments in quasi-three-component systems (aliphatic/ aliphatic, aliphatic/toluene and thiophene/pyridine binaries) were taken from our previous papers, ${ }^{20}$ i.e. they were estimated as described therein.

The attempt to calculate the extraction separation by means of the given set of parameters yielded, however, the compositions of two equilibrium phases, which did not correspond to the experimental observation. Thus, for the system with ChCl-EG 1:2, with the ratio DES / model gasoline of $0.25 \mathrm{~kg} \mathrm{~kg}^{-1}$ and with the NRTL model, the raffinate phase composition (in mass fractions) of $w^{R}=\{0.2477$, $0.2594,0.2455,0.1015,0.0744,0.0715,0.0000\}$ was obtained; the corresponding extract phase composition $W^{\mathrm{E}}=\{0.1819,0.1904,0.1802,0.0691,0.0120,0.0292$, $0.3371\}$ was calculated. The result points to the extraction of excessive amounts of aliphatic components. For the same system, using the UNIQUAC model, the raffinate phase composition was $w^{R}=\{0.2631,0.2756,0.2608,0.1038$, $0.0462,0.0502,0.0003\}$ and the extract phase composition was $w^{\mathrm{E}}=\{0.0000,0.0000,0.0000,0.0000,0.0037$, $0.0320,0.9642\}$. In the raffinate phase, a too large mass fraction of DES was calculated and in the extract phase the amount of extracted substances was too low, with the mass fraction of extracted toluene being three orders of magnitude smaller $\left(w \approx 10^{-9}\right)$ than the mass fraction of extracted aliphatic hydrocarbons $\left(w \approx 10^{-6}\right)$. Since such a procedure of direct transfer of parameters appears to be a dead end, parameters for other systems are available only on request, as supplemental information.

It is interesting to try to explain the possible causes of the observed deviations here. One has to assume that the binary interaction parameters determined in quasi-three-component systems carry the wrong or too little experimental information. For example, it was not possible to determine the mass fraction of DES in the raffinate phase by the described experiment or the mass fraction of hydrocarbons in the extract phase, because they were below the detection limit of the method. Therefore, they were assumed to be zero, or for the purpose of computation, they were assigned an arbitrary low value of $\sim 10^{-6}$. Quasi-three-component systems were successfully described by the models, but the resulting interaction parameters did not contain true experimental but mere arbitrary information. This problem could only be solved by a different experiment. For systems with a small but measurable hydrocarbon solubility in DES, an alternative experimental method for determining the equilibrium phase composition is, for example, ${ }^{1} \mathrm{H} N \mathrm{NR}^{16}$. For systems with extreme insolubility, gas chromatography on a stationary phase impregnated with a non-volatile liquid extraction medium can also be applied, which is in fact a description of gas-liquid chromatography (GLC). The method was experimentally applied for ionic 
Table 8 - Example of a complete NRTL and UNIQUAC model interaction parameter set obtained by simple transfer of parameters from quasi-three-component to quasi-seven-component systems. All $\alpha$-parameters of NRTL model are set to 0.3.

Tablica 8 - Primjer potpunoga skupa interakcijskih parametara modela NRTL i UNIQUAC dobivenoga jednostavnim prijenosom parametara iz kvazi-trokomponentnih u kvazi-sedmerokomponentne sustave. Svi $\alpha$-parametri modela NRTL postavljeni su na 0.3 .

\begin{tabular}{|c|c|c|c|c|c|c|c|}
\hline NRTL & $n$-hexane & $n$-heptane & $i$-octane & toluene & thiophene & pyridine & ChCl-EG $1: 2$ \\
\hline n-hexane & 0 & 0.1398 & 0.2700 & 0.8425 & 14.2343 & 1.4969 & 15.6024 \\
\hline$n$-heptane & -0.1428 & 0 & 0.1206 & 0.9016 & 14.2343 & 1.4969 & 15.6024 \\
\hline$i$-octane & -0.2814 & -0.1228 & 0 & 0.8795 & 14.2343 & 1.4969 & 15.6024 \\
\hline toluene & -0.5900 & -0.6595 & -0.6579 & 0 & 14.6024 & 12.5490 & 14.0906 \\
\hline thiophene & 19.2008 & 19.2008 & 19.2008 & 18.1996 & 0 & 1.2960 & 5.8228 \\
\hline pyridine & 9.2895 & 9.2895 & 9.2895 & 7.8654 & -0.8452 & 0 & 16.0795 \\
\hline ChCl-EG 1:2 & 10.8969 & 10.8969 & 10.8969 & 9.4131 & 0.9355 & 1.0909 & 0 \\
\hline UNIQUAC & $n$-hexane & $n$-heptane & $i$-octane & toluene & thiophene & pyridine & ChCl-EG 1:2 \\
\hline$n$-hexane & 1 & 1 & 1 & 0.5184 & 2.3734 & 0.9880 & 0.5015 \\
\hline n-heptane & 1 & 1 & 1 & 0.5237 & 2.3734 & 0.9880 & 0.5015 \\
\hline$i$-octane & 1 & 1 & 1 & 0.5288 & 2.3734 & 0.9880 & 0.5015 \\
\hline toluene & 1.6470 & 1.6380 & 1.6290 & 1 & 2.3975 & 1.2982 & 0.1855 \\
\hline thiophene & 0.2005 & 0.2005 & 0.2005 & 0.1535 & 1 & 0.4197 & 0.0767 \\
\hline pyridine & 0.4642 & 0.4642 & 0.4642 & 0.0867 & 1.7690 & 1 & 0.0052 \\
\hline ChCl-EG 1:2 & 0.1681 & 0.1681 & 0.1681 & 0.0058 & 1.1397 & 1.8090 & 1 \\
\hline
\end{tabular}

liquids ${ }^{18,24-27}$ and DESs. ${ }^{28}$ The method provides the activity coefficients at infinite dilution which bear the key experimental information.

Without measurable levels of DES in the raffinate phase, it was not possible to evaluate quantitatively the interaction of hydrocarbons with pyridine or thiophene. Namely, pyridine and thiophene are completely miscible with all the investigated hydrocarbons. Parameters of interaction of fully miscible components can be estimated, e.g., from experimental data on vapour-liquid equilibrium, but the application of those parameters to the liquid-liquid equilibrium is unreliable in principle. This is a well-known fact, and that is why the interaction parameters of the UNIFAC model for vapour-liquid equilibrium differ from those for liquid-liquid equilibrium modelling, i.e. there exist different versions of the parameter tables. ${ }^{21,29,30}$ Ideally, the interaction parameters of miscible component pairs can be transferred from another, similar system, containing an extraction agent significantly more soluble in pyridine/hydrocarbon or thiophene/hydrocarbon mixtures. Fortunately, here it was possible to use data from previous research in similar systems, with ionic liquid as an extraction medium. ${ }^{20}$

Therefore, a procedure for determining unknown interaction parameters for DES/low molecular weight component pairs was designed using directly the liquid-liquid equilibria measurements in quasi-seven-component systems. Firstly, all interaction parameters for low molecular component pairs were taken from the literature. ${ }^{20}$ Further, based on the mutual similarity of the phase diagrams in quasi-three-components systems with aliphatic hydrocarbons it is assumed that the aliphatic/DES pair interaction can be described by a unique pair of parameters: $\left\{\tau_{\mathrm{A} 7}=\tau_{17}=\tau_{27}=\tau_{37}, \tau_{7 \mathrm{~A}}=\tau_{71}=\tau_{72}=\tau_{73}\right\}$. In this way, the problem is reduced to the simultaneous determination of eight interaction parameters: $\tau_{\mathrm{A} 7}, \tau_{47}, \tau_{57}, \tau_{67}, \tau_{7 \mathrm{~A}}, \tau_{74}, \tau_{75}$ and $\tau_{76}$. The modified two-step Sørensen-Arlt procedure was performed according to the expressions:

$$
\begin{gathered}
O F_{5}=\sum_{j=1}^{n_{d}} \sum_{i=1}^{n_{c}}\left(\frac{x_{i}^{\mathrm{R}} \gamma_{i}^{\mathrm{R}}-x_{i}^{\mathrm{E}} \gamma_{i}^{\mathrm{E}}}{x_{i}^{\mathrm{R}} \gamma_{i}^{\mathrm{R}}+x_{i}^{\mathrm{E}} \gamma_{i}^{\mathrm{E}}}\right)_{j}^{2}+ \\
+Q\left(\tau_{\mathrm{A} 7}^{2}+\tau_{47}^{2}+\tau_{57}^{2}+\tau_{67}^{2}+\tau_{7 \mathrm{~A}}^{2}+\tau_{74}^{2}+\tau_{75}^{2}+\tau_{76}^{2}\right) \\
O F_{6}=\sum_{j=1}^{n_{d}} \sum_{i=1}^{n_{c}} \sum_{p=R, \mathrm{E}}\left[\left(w_{i}^{p}\right)_{\exp }-\left(w_{i}^{p}\right)_{\bmod }\right]_{j}^{2}+ \\
+Q\left(\tau_{A 7}^{2}+\tau_{47}^{2}+\tau_{57}^{2}+\tau_{67}^{2}+\tau_{7 \mathrm{~A}}^{2}+\tau_{74}^{2}+\tau_{75}^{2}+\tau_{76}^{2}\right)
\end{gathered}
$$

The optimal model parameters are shown in Table 9, which gives all interaction parameters for the DES system with ChCl-EG 1:2 as an example. Tables 10 and 11 provide all the interaction parameters determined in this paper. 
Table 9 - Example of a complete NRTL and UNIQUAC model interaction parameter set obtained by 1) transferring parameters for low molecular weight component pairs from literature data on seven-component systems ${ }^{20}$ and 2) optimization of DES-related interaction parameters with respect to experimental data in quasi-seven-component systems (this work). All $\alpha$-parameters of NRTL model are set to 0.3 .

Tablica 9 - Primjer potpunoga skupa interakcijskih parametara modela NRTL i UNIQUAC dobivenoga 1) prijenosom parametara za parove niskomolekulskih komponenata iz literaturnih podataka o sedmerokomponentnim sustavima ${ }^{20}$ i 2) optimiranjem parametara povezanim s DES-ovima prema eksperimentalnim podatcima u kvazi-sedmerokomponentnim sustavima iz ovoga rada. Svi $\alpha$-parametri modela NRTL postavljeni su na 0.3 .

\begin{tabular}{|c|c|c|c|c|c|c|c|}
\hline NRTL & $n$-hexane & $n$-heptane & $i$-octane & toluene & thiophene & pyridine & ChCl-EG 1:2 \\
\hline n-hexane & 0 & 0.1398 & 0.2700 & 0.8425 & -0.0629 & 1.2504 & 5.8506 \\
\hline n-heptane & -0.1428 & 0 & 0.1206 & 0.9016 & -1.0997 & 1.0673 & 5.8506 \\
\hline$i$-octane & -0.2814 & -0.1228 & 0 & 0.8795 & -0.3767 & 1.1947 & 5.8506 \\
\hline toluene & -0.5900 & -0.6595 & -0.6579 & 0 & -0.5990 & 1.8554 & 2.5965 \\
\hline thiophene & 0.6560 & 1.0528 & 0.9689 & -0.4575 & 0 & 1.2960 & 11.8095 \\
\hline pyridine & 0.9255 & 1.1736 & 1.2711 & 1.1988 & -0.8452 & 0 & 1.8695 \\
\hline ChCl-EG 1:2 & 5.9858 & 5.9858 & 5.9858 & -1.3317 & -0.4157 & -0.3100 & 0 \\
\hline UNIQUAC & $n$-hexane & $n$-heptane & i-octane & toluene & thiophene & pyridine & ChCl-EG $1: 2$ \\
\hline n-hexane & 1 & 1 & 1 & 0.5184 & 0.3659 & 0.5109 & 0.0254 \\
\hline$n$-heptane & 1 & 1 & 1 & 0.5237 & 0.2711 & 0.6907 & 0.0254 \\
\hline$i$-octane & 1 & 1 & 1 & 0.5288 & 0.7013 & 0.4855 & 0.0254 \\
\hline toluene & 1.6470 & 1.6380 & 1.6290 & 1 & 1.6860 & 1.3556 & 1.8899 \\
\hline thiophene & 1.2831 & 1.9127 & 0.9839 & 0.5306 & 1 & 0.4197 & 2.1670 \\
\hline pyridine & 1.1539 & 0.9648 & 1.1954 & 2.3717 & 1.7690 & 1 & 0.0152 \\
\hline ChCl-EG 1:2 & 0.0221 & 0.0221 & 0.0221 & 0.1331 & 0.1166 & 3.7256 & 1 \\
\hline
\end{tabular}

Table 10 - NRTL and UNIQUAC model interaction parameters calculated in this work - Part 1. Only parameters that vary with the choice of DES are shown. All $\alpha$-parameters of NRTL model are set to 0.3 .

Tablica 10 - Interakcijski parametri modela NRTL i UNIQUAC izračunati u ovom radu - prvi dio. Prikazani su samo parametri koji se mijenjaju s izborom DES-a. Svi $\alpha$-parametri modela NRTL postavljeni su na 0.3.

\begin{tabular}{l|c|c|c|c|c|c}
\hline \multicolumn{1}{c}{ NRTL } & ChCl-EG 1:2 & ChCl-EG 1:3 & ChCl-EG 1:3.5 & ChCl-Gly 1:1.5 & ChCl-Gly 1:2 & ChCl-Gly 1:3 \\
\hline aliphatic & 5.8506 & 5.6490 & 6.3964 & 7.7397 & 5.9927 & 7.0309 \\
toluene & 2.5965 & 2.2527 & 2.0252 & 14.2636 & 14.6326 & 18.2285 \\
thiophene & 11.8095 & 17.6728 & 16.9290 & 16.7038 & 22.1281 & 23.3944 \\
pyridine & 1.8695 & 1.0786 & 2.9120 & 0.5040 & 0.0414 & -0.2980 \\
\hline UNIQUAC & ChCl-EG 1:2 & ChCl-EG 1:3 & ChCl-EG 1:3.5 & ChCl-Gly 1:1.5 & ChCl-Gly 1:2 & ChCl-Gly $1: 3$ \\
\hline aliphatic & 0.0254 & 0.0398 & 0.0525 & 0.4298 & 0.0202 & 0.0445 \\
toluene & 1.8899 & 1.6570 & 1.6145 & 1.5952 & 0.9282 & 1.4692 \\
thiophene & 2.1670 & 0.9414 & 1.3751 & 2.2217 & 1.9440 & 2.1001 \\
pyridine & 0.0152 & 0.0475 & 0.0338 & 0.1591 & 0.1936 & 0.2459 \\
\hline
\end{tabular}


Table 11 - NRTL and UNIQUAC model interaction parameters calculated in this work - Part 2. Only parameters that vary with the choice of DES are shown. All $\alpha$-parameters of NRTL model are set to 0.3 .

Tablica 11 - Interakcijski parametri modela NRTL i UNIQUAC izračunati u ovom radu - drugi dio. Prikazani su samo parametri koji se mijenjaju s izborom DES-a. Svi $\alpha$-parametri modela NRTL postavljeni su na 0.3 .

\begin{tabular}{l|c|c|c|c}
\hline NRTL & aliphatic & toluene & thiophene & pyridine \\
\hline ChCl-EG 1:2 & 5.9858 & -1.3317 & -0.4157 & -0.3100 \\
ChCl-EG 1:3 & 5.6168 & -1.2924 & -0.7613 & -0.6830 \\
ChCl-EG 1:3.5 & 5.3803 & -1.3533 & -0.7176 & -1.8444 \\
ChCl-Gly 1:1.5 & 4.5033 & 17.7687 & 25.8397 & 22.6089 \\
ChCl-Gly 1:2 & 3.6891 & 20.7472 & 23.1096 & 20.9226 \\
ChCl-Gly 1:3 & 5.0203 & 18.6298 & 25.9942 & 22.7379 \\
\hline UNIQUAC & aliphatic & toluene & thiophene & pyridine \\
\hline ChCl-EG 1:2 & 0.0221 & 0.1331 & 0.1166 & 3.7256 \\
ChCl-EG 1:3 & 0.0136 & 0.4463 & 0.5176 & 3.0445 \\
ChCl-EG 1:3.5 & 0.0129 & 0.3113 & 0.4224 & 4.5538 \\
ChCl-Gly 1:1.5 & 0.0437 & 0.2246 & 0.0052 & 7.8535 \\
ChCl-Gly 1:2 & 0.0209 & 0.6952 & 0.0345 & 13.5865 \\
ChCl-Gly 1:3 & 0.0336 & 0.5110 & 0.0137 & 2.8563 \\
\hline
\end{tabular}

Based on the obtained parameters, the equilibrium compositions of both phases were calculated. The results are numerically shown in the tables, as compared to the experimental values; the tables are given in the supplemental

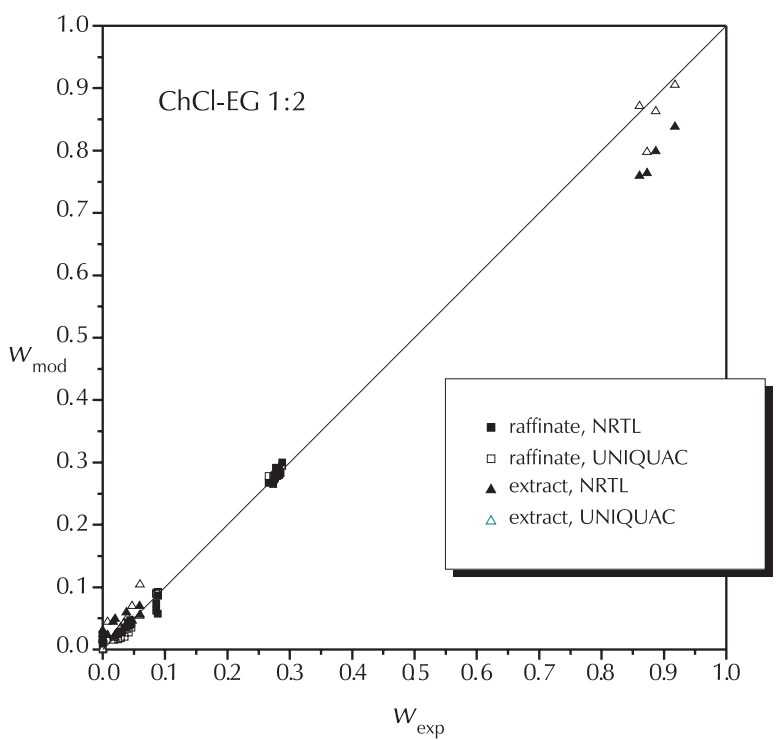

Fig. 9 - Comparison of experimental and calculated component distributions (mass fractions) for quasi-seven-component systems with DES / model gasoline ratio of $0.25 \mathrm{~kg} \mathrm{~kg}^{-1}$ whole composition range

Slika 9 - Usporedba eksperimentalnih i izračunatih raspodjela komponenata (masenih udjela) za kvazi-sedmerokomponentne sustave s omjerom DES / modelno gorivo od $0,25 \mathrm{~kg} \mathrm{~kg}^{-1}$ - cijelo područje sastava information, due to their extensiveness. The same comparison is presented graphically for a selected system in Figs. 9-12.

As an illustration, for the system with ChCl-EG 1:2, with DES / model gasoline ratio of $0.25 \mathrm{~kg} \mathrm{~kg}^{-1}$ and with the NRTL model, the calculated composition of the raffinate phase (in mass fractions) was $w^{R}=\{0.2674,0.2802$, $0.2654,0.0864,0.0422,0.0434,0.0149\}$ and the composition of the extract phase was $w^{\mathrm{E}}=\{0.0296,0,0304$, $0.0283,0.0698,0.0228,0.0556,0.7634\}$. For the same system, using the UNIQUAC model, the composition of the raffinate phase was $W^{R}=\{0.2784,0.2916,0.2760$, $0.0917,0.0351,0.0273,0.0000\}$ and the composition of the extract phase was $w^{\mathrm{E}}=\{0.0001,0.0000,0.0000$, $0.0541,0.0444,0.1037,0.7977\}$. At a first glance, it seems that the results for both models are quite satisfactory; in Fig. 9, experimental vs. model mass fractions are nicely distributed around the diagonal. Yet, certain characteristic deviations can be recognized. A preferred extraction of pyridine, toluene and thiophene with respect to aliphatic hydrocarbons is described by both models. Pyridine is the best extracted component, followed by toluene and thiophene, see Fig. 10. However, the NRTL model predicts significant extracted amounts of aliphatic compounds, not confirmed by the experiments, as seen by a group of data points within the shaded elliptic region of Fig. 10. On the other hand, the UNIQUAC model does not predict the occurrence of aliphatic hydrocarbons in the extract phase; see data points within the shaded circle encompassing the origin of the diagram in Fig. 10. Fig. 11 shows the medium concentration range, i.e. mass fractions of aliphatic hydrocarbons in the raffinate phase. Both models produce similar results and the dispersion of data may serve to as-

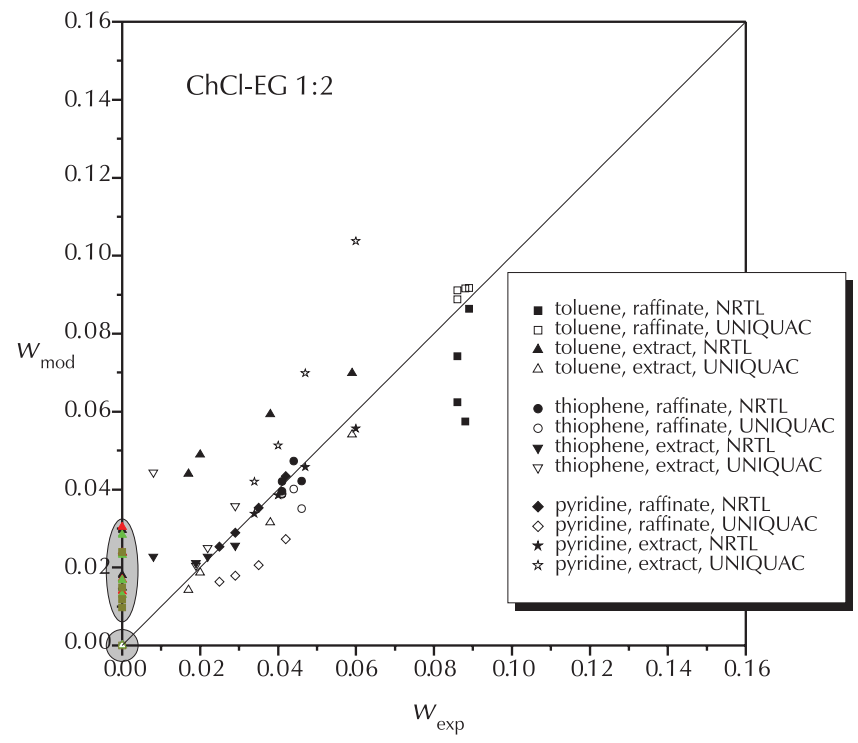

Fig. 10 - Comparison of experimental and calculated component distributions (mass fractions) for quasi-seven-component systems with DES / model gasoline ratio of $0.25 \mathrm{~kg} \mathrm{~kg}^{-1}$ - lower mass fraction range

Slika 10 - Usporedba eksperimentalnih i izračunatih raspodjela komponenata (masenih udjela) za kvazi-sedmerokomponentne sustave s omjerom DES / modelno gorivo od $0,25 \mathrm{~kg} \mathrm{~kg}^{-1}$ - područje manjih masenih udjela 


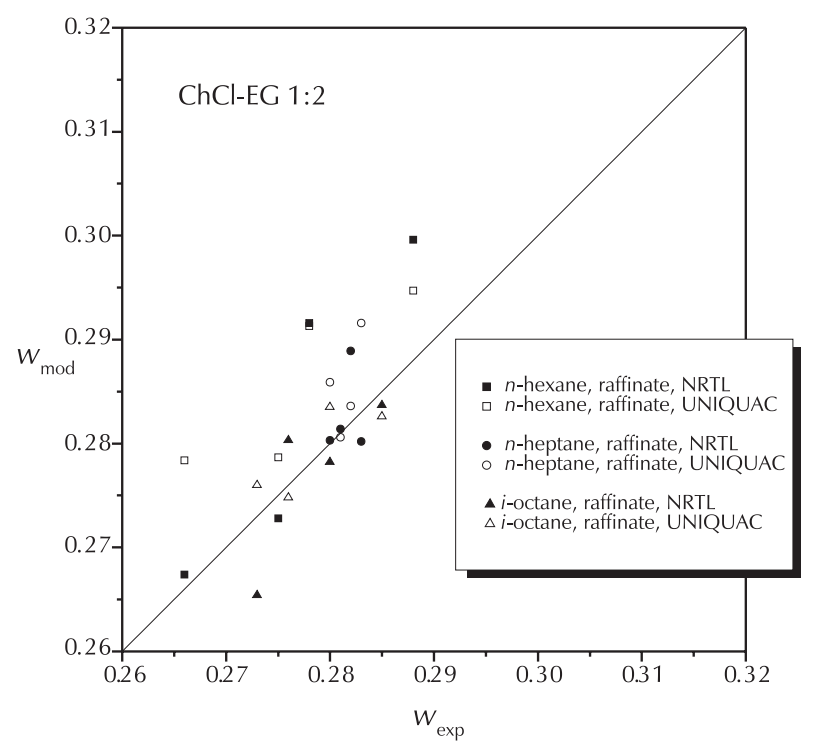

Fig. 11 - Comparison of experimental and calculated component distributions (mass fractions) for quasi-seven-component systems with DES / model gasoline ratio of $0.25 \mathrm{~kg} \mathrm{~kg}^{-1}$ - middle mass fraction range

Slika 11 - Usporedba eksperimentalnih i izračunatih raspodjela komponenata (masenih udjela) za kvazi-sedmerokomponentne sustave s omjerom DES / modelno gorivo od $0,25 \mathrm{~kg} \mathrm{~kg}^{-1}$ - područje srednjih masenih udjela

sess the measurement uncertainty of the method used to determine equilibrium compositions. In Fig. 12, the higher concentration range is shown. Here, one can observe only the data points corresponding to the DESs concentrations in the extract phase. A better agreement with experimental data is obtained by the UNIQUAC model. Namely, the NRTL model with the given set of parameters produces a rather large solubility of DESs in the raffinate phase; see other data points within the shaded elliptic region of Fig. 10. The amount of DES dissolved in raffinate is therefore missing in the extract phase.

Generally speaking, the results obtained by both models using the second set of interaction parameters (where a part of parameters is transferred from the closely related seven-component systems with the ionic liquid, and the other part is obtained by optimization from the experimental findings in the quasi-seven-component systems with the corresponding DESs) are better than those calculated with the first set of parameters (where all the parameters are transferred from the matching quasi-three-component systems with no additional optimization). This is particularly evident in the toluene solubility in DESs. The experiments in quasi-three-component systems point to negligible solubility of toluene in all DESs; yet the corresponding solubility in quasi-seven-component systems is clearly expressed. Obviously, the simple transfer of parameters from the three-component-systems cannot give good results there. In addition, it is quite apparent that the UNIQUAC model proved to perform better than the NRTL model, particularly in correlating the insolubility of DESs in the raffinate phase, as well the insolubility of aliphatics in the extract phase.

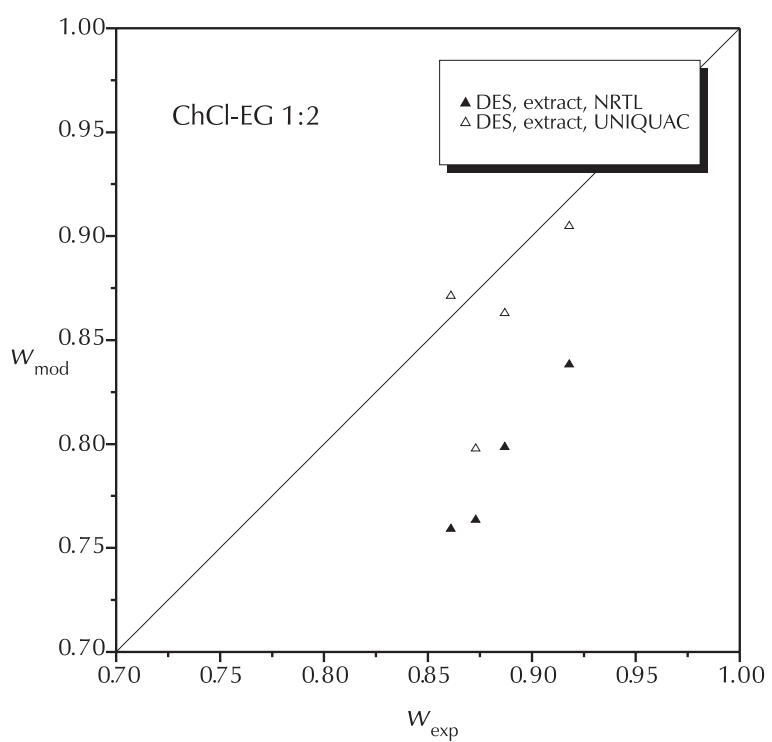

Fig. 12 -Comparison of experimental and calculated component distributions (mass fractions) for quasi-seven-component systems with DES / model gasoline ratio of $0.25 \mathrm{~kg} \mathrm{~kg}^{-1}$ - higher mass fraction range

Slika 12 - Usporedba eksperimentalnih i izračunatih raspodjela komponenata (masenih udjela) za kvazi-sedmerokomponentne sustave s omjerom DES / modelno gorivo od $0,25 \mathrm{~kg} \mathrm{~kg}^{-1}$ - područje viših masenih udjela

\section{Conclusions}

As part of a wider research into the possibilities of extracting sulphur and nitrogen compounds from hydrocarbon fuels using deep eutectic solvents, this paper describes the determination of the liquid-liquid phase equilibria in a series of quasi-three-component systems with aliphatic or aromatic hydrocarbons as the first component, thiophene or pyridine as the second component, and selected DESs based on choline chloride and ethylene glycol, or choline chloride and glycerol in different proportions as the third component. Based on the assumption that DESs could be regarded as quasi-components, the interaction parameters of the NRTL and UNIQUAC models have been determined to describe the obtained experimental equilibria. On the basis of previous positive experiences in systems with ionic liquids as extraction media, an attempt was made to simply transfer parameters from quasi-three-component to quasi-seven-component systems that are much closer to the expected real industrial situation. However, the expected agreement with experimental results was not obtained. Therefore, a new computational procedure was designed in which a part of the models' interaction parameters was transmitted from existing literature data, and a part was determined by optimizing directly from the experimental data on the liquid-liquid equilibria in quasi-seven-component systems. This approach has proven to be significantly better. A fairly good agreement between the experimental and the model data was obtained, especially with the UNIQUAC model, and the limitations of the models were discussed. It is assumed that the set of interaction parameters obtained in this paper could be applied to the description of similar experiments in the same systems or that the ap- 
proach described here could be applied to other, related systems during future research.

\section{ACKNOWLEDGMENT}

The authors are grateful for the financial support from the Croatian Science Foundation, under the project Green Solvents for Green Technologies (9550).

\section{List of abbreviations and symbols Popis kratica i simbola}

\section{Symbols}

Simboli

A $\quad$ - average absolute deviation of experimental and calculated mass fractions, 1

- srednje kvadratno odstupanje eksperimentalnih i izračunatih masenih udjela, 1

$A, B, C, D$ - parameters of empirical correlation of composition vs. refractive index

- parametri empirijske korelacije sastava i indeksa loma

exp - subscript denoting experimental value

- indeks što označava eksperimentalnu vrijednost

E $\quad-$ (in subscript) extract phase

- (u indeksu) ekstraktna faza

$g^{\text {ex }} \quad-$ molar excess Gibbs energy, $\mathrm{J} \mathrm{mol}^{-1}$

- molarna eksces Gibbsova energija, J mol ${ }^{-1}$

$g^{\text {ex }, \mathrm{C}} \quad-$ combinatorial part of molar excess Gibbs energy in UNIQUAC model, $\mathrm{J} \mathrm{mol}^{-1}$

- kombinatorni doprinos molarnoj eksces Gibbsovoj energiji u modelu UNIQUAC, J $\mathrm{mol}^{-1}$

$g^{\text {ex,R }} \quad-$ residual part of molar excess Gibbs energy in UNIQUAC model, I $\mathrm{mol}^{-1}$

- rezidualni doprinos molarnoj eksces Gibbsovoj energiji u modelu UNIQUAC, J $\mathrm{mol}^{-1}$

$G_{i j} \quad$ - symbol appearing in NRTL model, exponential function of model parameters, 1

- simbol koji se pojavljuje u modelu NRTL, eksponencijalna funkcija parametara modela, 1

$I_{i} \quad$ - bulk factor of correlation by Domańska

- volumni faktor korelacije Domańske

mod - subscript denoting model or calculated value

- indeks koji označava modelnu ili računsku vrijednost

$n_{\mathrm{c}} \quad$ - number of components

- brojnost komponenata

$n_{\mathrm{d}} \quad-$ number of tie line experimental data points

- brojnost eksperimentalnih veznih linija

$n_{\mathrm{D}, 25} \quad$ - refractive index measured at $25{ }^{\circ} \mathrm{C}$ and using sodium D-lines

- indeks loma mjeren pri $25^{\circ} \mathrm{C}$ te pri svjetlosti natrijevih D-linija

$n_{\mathrm{g}} \quad-$ number of structural groups in component

- brojnost strukturnih grupa u komponenti

$O F_{1-6} \quad$ - objective function to be minimized, 1

- funkcija cilja koju se minimizira, 1

Q - penalization factor, 1

- kaznena funkcija, 1

$q_{i} \quad$ - surface parameter of component $i$ in UNIQUAC model, 1

- površinski parameter komponente $i$ u modelu UNIQUAC, 1
$Q_{k} \quad$ - surface parameter of structural group $k, 1$

- površinski parametar strukturne grupe $k, 1$

$R \quad$ - gas constant, $\mathrm{JK}^{-1} \mathrm{~mol}^{-1}$

- opća plinska konstanta, $\mathrm{JK}^{-1} \mathrm{~mol}^{-1}$

$\mathrm{R} \quad-$ (in subscript) raffinate phase

- (u indeksu) rafinatna faza

$r_{i} \quad$ - volume parameter of component $i$ in UNIQUAC model, 1

- volumni parametar komponente $i$ u modelu UNIQUAC, 1

$R_{k} \quad$ - volume parameter of structural group $k$

- volumni parametar strukturne grupe $k$

$T \quad$ - temperature, $\mathrm{K}$

- temperatura, $\mathrm{K}$

u $\quad-$ standard uncertainty, 1

- standardna mjerna nesigurnost, 1

$v_{i} \quad-$ molar volume of component $i, \mathrm{~m}^{3} \mathrm{~mol}^{-1}$

- molarni volumen komponente $i, \mathrm{~m}^{3} \mathrm{~mol}^{-1}$

$w_{i} \quad-$ mass fraction of component $i, 1$

- maseni udjel komponente $i, 1$

$x_{i} \quad-$ molar fraction of component $i, 1$

- molarni udjel komponente $i, 1$

- lattice coordination number

- koordinacijski broj rešetke

$\alpha_{i j} \quad-$ nonrandomness parameter of NRTL model, 1

- parametar neslučajnosti modela NRTL, 1

$\gamma_{i} \quad$ - activity coefficient of component $i, 1$

- koeficijent aktivnosti komponente $i, 1$

$\Theta_{i} \quad$ - surface fraction of component $i, 1$

- površinski udjel komponente $i, 1$

$\tau_{i j} \quad-$ interaction parameter of NRTL or UNIQUAC models, 1

- interakcijski parametar modela koeficijenta aktivnosti NRTL i UNIQUAC, 1

$\Phi_{i} \quad$ - volume fraction of component $i, 1$

- volumni udjel komponente $i, 1$

$\Psi \quad-$ mass fraction of a particular liquid phase

- maseni udjel pojedine kapljevite faze

\section{Abbreviations \\ Kratice}

CAD - Computer Aided Design

- računalom potpomognuto projektiranje

$\mathrm{ChCl} \quad$ - choline chloride

- kolin-klorid

COSMO-RS - COnductor like Screening MOdel for Real Solvents - a thermodynamic model for liquid solutions based on quantum chemistry calculations

- termodinamički model za kapljevite otopine zasnovan na kvantno-kemijskim proračunima

DES - Deep Eutectic Solvent

- niskotemperaturno eutektičko otapalo

EDS

- extractive desulphurization

- ekstrakcijska desulfurizacija

EG - ethylene glycol

- etilen-glikol

FCC - Fluid Catalytic Cracking

- katalitičko krekiranje u fluidiziranom (uzvitlanom) sloju katalizatora 
FID - Flame Ionization Detector

- plameno-ionizacijski detektor

GC - Gas Chromatography

- plinska kromatografija

Gly $\quad-$ glycerol

- glicerol

HDS - hydrodesulphurization

- hidrodesulfurizacija

IL $\quad$ - Ionic Liquid

- ionska kapljevina

NMR - Nuclear Magnetic Resonance

- nuklearna magnetska rezonancija

NRTL - Non-Random Two-Liquid - a correlative thermodynamic model for liquid solutions, 1

- korelativni termodinamički model za kapljevite otopine, 1

UNIFAC - UNIquac Functional group Activity Coefficients - a predictive thermodynamic model for liquid solutions

- prediktivni termodinamički model za kapljevite otopine

UNIQUAC - UNIversal QUAsiChemical - a correlative thermodynamic model for liquid solutions, 1

- korelativni termodinamički model za kapljevite otopine, 1

\section{References \\ Literatura}

1. C. Capello, U. Fischer, K. Hungerbuhler, What is a green solvent? A comprehensive framework for the environmental assessment of solvents, Green Chem. 9 (2007) 927-934, doi: https://doi.org/10.1039/b617536h.

2. A. P. Abbott, R. C. Harris, K. S. Ryder, C. D'Agostino, L. F. Gladden, M. D. Mantle, Glycerol eutectics as sustainable solvent systems, Green Chem. 13 (2011) 82-90, doi: https:// doi.org/10.1039/c0gc00395f.

3. M. Freemantle, Designer solvents - Ionic liquids may boost clean technology development, Chem. Eng. News 76 (1998) 32-37, doi: https://doi.org/10.1021/cen-v076n013.p032 .

4. I. Anugwom, P. Maki-Arvela, T. Salmi, J.-P. Mikkola, Ionic liquid assisted extraction of nitrogen and sulfur-containing air pollutants from model oil and regeneration of the spent ionic liquid, J. Environ. Prot. 2 (2011) 796-802, doi: https://doi. org/10.4236/jep.2011.26091.

5. C. Shu, T. Sun, Extractive desulfurisation of gasoline with tetrabutyl ammonium chloride-based deep eutectic solvents, Separ. Sci. Technol. 51 (2016) 1336-1343, doi: https://doi. org/10.1080/01496395.2016.1155602.

6. F. Pena-Pereira, J. Namieśnik, lonic liquids and deep eutectic mixtures: sustainable solvents for extraction processes, Chem. Sus. Chem. 7 (2014) 1784-1800, doi: https://doi. org/10.1002/cssc.201301192.

7. A. Stanislaus, A. Marafi, M. S. Rana, Recent advances in the science and technology of ultra low sulfur diesel (ULSD) production, Catal. Today 153 (2010) 1-68, doi: https://doi. org/10.1016/j.cattod.2010.05.011.

8. C. D. Wilfred, C. F. Kiat, Z. Man, M. A. Bustam, M. I. M. Mutalib, C. Z. Phak, Extraction of dibenzothiophene from dodecane using ionic liquids, Fuel Process. Technol. 93 (2012) 85-89, doi: https://doi.org/10.1016/j.fuproc.2011.09.018.

9. M. A. Ceron, D. J. Guzman-Lucero, J. F. Palomenque, R. Martinez-Palou, Parallel microwave-assisted synthesis of ionic liquids and screening for denitrogenation of straight-run diesel feed by liquid-liquid extraction, Comb. Chem. High Throughput Screen 15 (2012) 427-432, doi: https://doi. org/10.2174/138620712800194477.

10. M. F. Casal, Desulfurization of Fuel Oils by Solvent Extraction with Ionic Liquids, PhD thesis, University of Santiago de Compostela, Santiago de Compostela, 2010, https://minerva.usc.es/xmlui/bitstream/handle/10347/10019/rep_621. pdf? sequence $=1$ (3. 3. 2018.).

11. C. Song, An overview of new approaches to deep desulfurization for ultra-clean gasoline, diesel fuel and jet fuel, Catal. Today 86 (2003) 211-263, doi: https://doi.org/10.1016/ S0920-5861(03)00412-7.

12. J-J. Li, H. Xiao, X.-D. Tang, M. Zhou, Green carboxylic acid-based deep eutectic solvents as solvents for extractive desulfurization, Energ. Fuel 30 (2016) 5411-5418, doi: https://doi.org/10.1021/acs.energyfuels.6b00471.

13. C. Li, D. Li, S. Zou, Z. Li, J. Yin, A. Wang, Y. Cui, Z. Yao, Q. Zhao, Extraction desulfurization process of fuels with ammonium based deep eutectic solvents, Green Chem. 15 (2013) 2793-2799, doi: https://doi.org/10.1039/c3gc41067f.

14. Z. S. Gano, F. S., Mjalli, T. Al-Wahaibi, Y. Al-Wahaibi, I. M. AlNashef, Extractive desulfurization of liquid fuel with Fe$\mathrm{Cl}_{3}$-based deep eutectic solvents: Experimental design and optimization by central-composite design, Chem. Eng. Process. 93 (2015) 10-20, doi: https://doi.org/10.1016/j. cep.2015.04.001.

15. M. C. Ali, Q. Yang, A. A. Fine, W. Jin, Z. Zhang, H. Xing, Q. Ren, Efficient removal of both basic and non-basic nitrogen compounds from fuels by deep eutectic solvents, Green Chem. 18 (2016) 157-164, doi: https://doi.org/10.1039/ c5gc01823d.

16. H. F. Hizaddin, M. K. Hadj-Kali, A. Ramalingam, M. A. Hashim, Extractive denitrogenation of diesel fuel using ammoniumand phosphonium-based deep eutectic solvents, J. Chem. Thermodyn. 95 (2016) 164-173, https://doi.org/10.1016/j. jct.2015.12.009.

17. A. Sander, M. Rogošić, A. Slivar, B. Žuteg, Separation of hydrocarbons by means of liquid-liquid extraction with deep eutectic solvents, Solvent Extr. Ion Exc. 34 (2016) 86-98, doi: https://doi.org/10.1080/07366299.2015.1132060.

18. U. Domańska, M. Laskowska, Measurements of activity coefficients at infinite dilution of aliphatic and aromatic hydrocarbons, alcohols, thiophene, tetrahydrofuran, MTBE, and water in ionic liquid [BMIM][SCN] using GLC, J. Chem. Thermodyn. 41 (2009) 645-650, doi: https://doi.org/10.1016/j. jct.2008.12.018.

19. M. Rogošić, A. Sander, V. Kojić, J. Parlov Vuković, Liquid-liquid equilibria in the ternary and multicomponent systems involving hydrocarbons, thiophene or pyridine and ionic liquid (1-benzyl-3-metylimidazolium bis(trifluorometylsulfonyl) imide), Fluid Phase Equilib. 412 (2016) 39-50, doi: https:// doi.org/10.1016/j.fluid.2015.12.025.

20. A. Sander, M. Rogošić, B. Ferčec, J. Parlov Vuković, Liquidliquid equilibrium for the systems hydrocarbon-thiophene or pyridine-1-hexyl-3,5-dimethylpyridinium bis(trifluoromethylsulfonyl)imide, Sep. Sci. Technol. 52 (2017) $2557-$ 2572, doi: https://doi.org/10.1080/01496395.2017.137367 4.

21. T. Magnussen, P. Rasmussen, A. Fredenslund, UNIFAC parameter table for prediction of liquid-liquid equilibria, Ind. Eng. Chem. Process Des. Dev. 20 (1981) 331-339, doi: https:// doi.org/10.1021/i200013a024.

22. U. Domańska, Solubility of $n$-alkanols $\left(\mathrm{C}_{16}, \mathrm{C}_{18}, \mathrm{C}_{\mathrm{m}}\right)$ in binary solvent mixtures, Fluid Phase Equilib. 46 (1989) 223-248, doi: https://doi.org/10.1016/0378-3812(89)80037-8. 
23. S. M. Walas, Phase Equilibria in Chemical Engineering, Elsevier, Amsterdam, 1985.

24. R. Kato, J. Gmehling, Activity coefficients at infinite dilution of various solutes in the ionic liquids $[\mathrm{MMIM}]^{+}\left[\mathrm{CH}_{3} \mathrm{SO}_{4}\right]^{-}$, $[\mathrm{MMIM}]^{+}\left[\mathrm{CH}_{3} \mathrm{OC}_{2} \mathrm{H}_{4} \mathrm{SO}_{4}\right]^{-}, \quad[\mathrm{MMIM}]^{+}\left[\left(\mathrm{CH}_{3}\right) 2 \mathrm{PO}_{4}\right]^{-}$, $\left[\mathrm{C}_{5} \mathrm{H}_{5} \mathrm{NC}_{2} \mathrm{H}_{5}\right]^{+}\left[\left(\mathrm{CF}_{3} \mathrm{SO}_{2}\right)_{2} \mathrm{~N}\right]^{-}$and $\left[\mathrm{C}_{5} \mathrm{H}_{5} \mathrm{NH}\right]^{+}\left[\mathrm{C}_{2} \mathrm{H}_{5} \mathrm{OC}_{2} \mathrm{H}_{4} \mathrm{O}-\right.$ $\left.\mathrm{SO}_{3}\right]^{-}$, Fluid Phase Equilib. 226 (2004) 37-44, doi: https:// doi.org/10.1016/j.fluid.2004.08.039.

25. S. Nebig, V. Liebert, J. Gmehling, Measurement and prediction of activity coefficients at infinite dilution $\left(\gamma^{\infty}\right)$, vapor-liquid equilibria (VLE) and excess enthalpies $\left(\mathrm{H}^{\mathrm{E}}\right)$ of binary systems with 1,1-dialkyl-pyrrolidinium bis(trifluoromethylsulfonyl)imide using mod. UNIFAC (Dortmund), Fluid Phase Equilib. 277 (2009) 61-67, doi: https://doi. org/10.1016/j.fluid.2008.11.013.

26. T. M. Letcher, D. Ramjugernath, M. Królikowski, M. Laskowska, P. Naidoo, U. Domańska, Activity coefficients at infinite dilution measurements for organic solutes in the ionic liquid N-butyl-4-methylpyridinium tosylate using GLC at $T=(328.15,333.15,338.15$, and 343.15)K, Fluid Phase
Equilib. 276 (2009) 31-36, doi: https://doi.org/10.1016/j. fluid.2008.10.008.

27. E. Olivier, T. M. Letcher, P. Naidoo, D. Ramjugernath, Activity coefficients at infinite dilution of organic solutes in the ionic liquid 1-ethyl-3-methylimidazolium trifluoromethanesulfonate using gas-liquid chromatography at $T=(313.15$, 323.15, and 333.15), J. Chem. Thermodynam. 42 (2010) 78-83, doi: https://doi.org/10.1016/j.jct.2009.07.010.

28. S. P. Verevkin, A. Yu. Sazonova, A. K. Frolkova, Dz. H. Zaitsau, I. V. Prikhodko, C. Held, Separation performance of biorenewable deep eutectic solvents, Ind. Eng. Chem. Res. 54 (2015) 3498-3504, doi: https://doi.org/10.1021/acs.iecr.5b00357.

29. S. Skjold-Joergensen, B. Kolbe, J. Gmehling, P. Rasmussen, Vapor-liquid equilibria by UNIFAC group contribution. revision and extension, Ind. Eng. Chem. Process Des. Dev. 18 (1979) 714-722, doi: https://doi.org/10.1021/ie00058a017.

30. U. Weidlich, J. Gmehling, A modified UNIFAC model. 1. Prediction of VLE, $h^{\mathrm{E}}$, and $\gamma^{\infty}$, Ind. Eng. Chem. Res. 26 (1987) 1372-1381, doi: https://doi.org/10.1021/ie00067a018.

\section{SAŽETAK \\ Modeliranje ravnoteže kapljevina-kapljevina u kvazi-sedmerokomponentnim sustavima s niskotemperaturnim eutektičkim otapalima kao ekstrakcijskim sredstvima \\ Marko Rogošić i Kristina Zagajski Kučan}

Eksperimentalno su istražene ravnoteže kapljevina-kapljevina u sustavima u kojem je prva komponenta alifatski ( $n$-heksan, $n$-heptan odnosno $i$-oktan) ili aromatski ugljikovodik (toluen), druga komponenta je piridin ili tiofen, a treća kvazi-komponenta je DES koji se sastoji od kolin klorida i glicerola, odnosno kolin klorida i etilen-glikola, pri $25{ }^{\circ} \mathrm{C}$ i atmosferskom tlaku. Ravnoteže su uspješno opisane modelima NRTL i UNIQUAC. Isti su modeli uspješno primijenjeni i za opis ravnoteža kapljevina-kapljevina i u kvazi-sedmerokomponentnim sustavima koji uključuju sve navedene niskomolekulske komponente i jedan DES. Raspravljena su ograničenja modela; čini se da se prednost može dati modelu UNIQUAC.

\section{Ključne riječi}

Niskotemperaturna eutektička otapala, NRTL, UNIQUAC, modelno gorivo, ravnoteža kapljevina-kapljevina

Sveučilište u Zagrebu, Fakultet kemijskog

inženjerstva i tehnologije

Marulićev trg 19, HR-10 000 Zagreb
Izvorni znanstveni rad Prispjelo 15. ožujka 2018. Prihvaćeno 14. travnja 2018. 